\title{
The Review of Single Subject Researches in the Field of Teaching Social Skills with Individuals with Intellectual Disabilities in Turkey
}

\author{
Serdar SÖNMEZ*a, Havva Aysun KARABULUT ${ }^{\mathrm{B}}$, Mehtap KOT ${ }^{\mathrm{C}}$, İlknur ÇİFCI \\ TEKINARSLAN $^{\mathrm{d}}$
}

\begin{tabular}{l} 
Article Info \\
\hline DOI: $10.14686 /$ buefad.334772 \\
\hline Article History: \\
Received: $\quad 15.08 .2017$ \\
Accepted: $\quad 15.04 .2018$ \\
Published: $\quad 30.06 .2018$ \\
\hline Keywords: \\
Individual with intellectual \\
disabilities \\
Social skill \\
Single subject research \\
\hline Article Type: Compilation \\
\end{tabular}

\begin{abstract}
Social skills are specific behaviors exhibited by individuals to fulfill roles or duties assigned by society. The difficulties that individuals with intellectual disabilities experience in acquiring social skills make it difficult for these individuals to integrate with society and negatively affect peer interaction. This increases the importance of studies aimed at teaching social skills that have an important place in the independent life of individuals with intellectual disabilities. The aim of this study is to examine the studies designed as the only single subject study of social skills teaching for individuals with intellectual disability, carried out between 2000-2017. This study is designed as a qualitative document analysis. 13 studies have been reached for the individuals with intellectual disabilities, including the published articles in peer-reviewed journals on social skills studies and the graduate and doctoral dissertations published in Turkey. The studies were examined and interpreted in eight categories: characteristics of subjects, dependent variable, independent variable, research design, monitoring, generalization, reliability and social validity data.
\end{abstract}

\section{Türkiye'de Zihin Yetersizliği Olan Bireylerle Sosyal Beceri Öğretimi Alanında Gerçekleștirilen Tek Denekli Araştırmaların İncelenmesi}

\begin{tabular}{|c|c|}
\hline \multicolumn{2}{|c|}{ Makale Bilgisi } \\
\hline \multicolumn{2}{|c|}{ DOI: $10.14686 /$ buefad.334772 } \\
\hline \multicolumn{2}{|c|}{ Makale Geçmişi: } \\
\hline Geliş: & 15.08 .2017 \\
\hline Kabul: & 15.04 .2018 \\
\hline Yayın: & 30.06 .2018 \\
\hline \multicolumn{2}{|c|}{$\begin{array}{l}\text { Anahtar Kelimeler: } \\
\text { Zihin yetersizliği olan birey } \\
\text { Sosyal beceri } \\
\text { Tek denekli araştırma }\end{array}$} \\
\hline Makale & $\ddot{u}$ : Derleme \\
\hline
\end{tabular}

\begin{abstract}
$\ddot{O} \mathbf{z}$
Sosyal beceriler, toplum tarafindan verilen görev ya da rolleri yerine getirmek için bireylerin sergiledikleri belirli davranışlardır. Zihin yetersizliği olan bireylerin sosyal becerileri edinmede yaşadıkları zorluklar bu bireylerin toplumla bütünleşmelerini güçleştirmekte ve akran etkileşimlerini olumsuz etkilemektedir. Bu durum zihin yetersizliği olan bireylerin bağımsız yaşamı için önemli bir yer tutan sosyal becerileri öğretmeyi amaçlayan çalışmaların önemini artırmaktadır. Bu çalışmanın amacı, 20002017 yılları arasında gerçekleştirilen, zihin yetersizliği olan bireylere yönelik sosyal beceri öğretiminin yapıldığı tek denekli araştırma olarak desenlenen çalışmaları incelemektir. $\mathrm{Bu}$ çalışma nitel bir doküman analizi olarak desenlenmiştir. Zihin yetersizliği olan bireylere sosyal beceri çalışmalarına ilişkin Türkiye'de hakemli dergilerde yayınlanmış makaleler ve yapılmış yüksek lisans ve doktora tezleri olmak üzere 13 çalışmaya ulaşılmıştır. Çalışmalar, deneklerin özellikleri, bağımlı değişken, bağımsız değişken, araştırma deseni, izleme, genelleme, güvenirlik ve sosyal geçerlik verileri olmak üzere sekiz kategoride incelenmiş ve yorumlanmıştır.
\end{abstract}

\footnotetext{
*Corresponding Author: serdarsonmez@live.com

${ }^{a}$ Research Assistant, Abant İzzet Baysal University, Bolu/Turkey, http://orcid.org/0000-0002-9050-3570

bLecturer, Abant İzzet Baysal University, Bolu/Turkey, http://orcid.org/0000-0001-9119-3626

${ }^{\mathrm{c}}$ Research Assistant, Abant İzzet Baysal University, Bolu/Turkey, http://orcid.org/0000-0002-1085-0645

${ }^{d}$ Associate Professor, Abant İzzet Baysal University, Bolu/Turkey, http://orcid.org/0000-0001-5028-3289
} 


\section{Introduction}

The aim for all individuals in education is to enable individuals to live independently in society (Snell and Brown, 2011). For special needs individuals, the main objective of education is to enable them to continue their lives independently and least dependently within the community and to fulfill community expectations, that is, to acquire the skills necessary to prepare them for social life (Çifci and Sucuoğlu, 2005; Dağseven-Emecen, 2011). To survive their lives independently depends on their inter-personal relationships as well as self-care, communication, academic and business skills (Çifci and Sucuoğlu, 2005). Individuals need social skills so they can demonstrate behaviors that enable them to be successful in interpersonal relationships (Avcioğlu, 2005). Social skills refer to behaviors that enable individuals to live their lives independently and in harmony with society and directly affect the quality of life of the individual (Mercer and Mercer, 2005). Social skills are an integral part of social life. For this reason, social skills play a very important role in human life (Bacanl1, 1999). From infancy, people learn many social skills from their immediate vicinity, that is, their parents, their siblings and their peers.

Normally developing individuals can learn social skills as a model of family, friends and adults, and in a nonsystematic way through observation, but in the case of individuals with intellectual disabilities, the acquisition of social skills is not achieved in this way and a teaching process is required. (Avcioğlu, 2005). The difficulties that individuals with intellectual disabilities experience in acquiring social skills make it difficult for these individuals to integrate into society and adversely affect their peer interaction. Teaching social skills will ensure that these negatives are addressed and will serve to increase the quality of life for individuals. (Avcioğlu, 2012-a). At this point, the question of how social skills can be gained is on the agenda. Many different methods and techniques can be used in the teaching of social skills. When literature is examined, it is seen that there are researches using modeling (Odluyurt, 2013), video modeling (Acar, 2015, Avcioglu, 2013, Emecen, 2008, Scattone, 2008, Sansosti and Powell-Smith, 2008, Paterson and Arco, 2007), shaping, behavioral rehearsal and role playing (Akfirat, 2004; Avcıoğlu, 2012-b; Eldeniz, 2005; İpek, 1998), direct instruction (Alptekin, 2010; Çakır, 2006; Özokçu, 2008), cognitive process approach (Çifci, 2001, Emecen, 2008), cooperative learning (Avcioğlu, 2001; Avcıoğlu, 2012a), self-management (Avcioğlu, 2012-b, Çelik, 2010) and basic response teaching (Harper et al., 2008; Pierce and Schreibman, 1995, 1997). It has been stated that researches in the field of literature have provided positive results in terms of teaching social skills to individuals who have intellectual disabilities can sustain their independent lives in society (Türer, 2010; Dağseven-Emecen, 2011; Alptekin, 2012; Avcığlu, 2012-a, 2012-b; Alptekin and Özyürek, 2013).

In many studies, it is stated that studies with individuals with intellectual disabilities provide positive results for the individuals. However, it is emphasized by experts that the methods used in studies of individuals with intellectual disabilities should be scientifically grounded, and even some that are transformed into necessities (Horner et al., 2005; Odom vd., 2005). Individuals with intellectual disabilities are thought to have evidence-based practices in order to demonstrate the positive results of social skills training for independent lives in society (Yücesoy-Özkan and Sönmez, 2011). Evidence-based practices are applications that show that there is sufficient evidence of research and are effective in finding out. The most basic step to be taken to determine these practices is to conduct meta-analysis studies (Yücesoy-Özkan and Sönmez, 2011). When literature is examined, it is seen that descriptive and meta-analysis studies related to social skills teaching are done to individuals with intellectual disabilities.

Bellini et al. (2007) conducted a meta-analysis study of 55 articles published between 1986 and 2005 to determine the effect sizes of teaching, retention and generalization. The aim of the study is to synthesize singlesubject research on school-based social skills teaching for students with autism spectrum disorder. Another aim of the study is to reveal the most effective teaching method for individuals with autism spectrum disorder bringing together the participant characteristics, application characteristics and research outputs. According to the results of this study, social skills education has limited influence for individuals with autism spectrum disorder. Individuals have difficulty in generalizing their skills. It has been observed that the lowest persistence is in the preschool period and the lowest generalization is in the individuals in the primary school period.

22 studies, published by the world and in Turkey between the years of 1991-2011 individuals with autism spectrum disorders using the social history of the teaching of social skills were examined by Sani-Bozkurt and Vuran (2014). The purpose of the study is to analyze the studies using social traits in teaching social skills to children with autism spectrum disorder. This study contains descriptive and meta-analysis of single-subject researches. According to the results of the research findings, social episodes should not be considered as an 
evidence-based practice to teach social skills to individuals with OSD yet. However, it is thought that social stories are promising for further research.

31 video modeling method, used teaching a variety of skills to individuals with autism spectrum disorder and made in Turkey and in the world, covering the years 2000 to 2010, were examined by Acar and Diken (2012). In the research, it was aimed to inform teachers and experts working on the field about the effectiveness of video model applications. Studies within the research were examined using descriptive analysis via descriptive summaries. According to the results obtained from the research findings, while the effectiveness of the method learned in the investigated studies was examined, efficiency was investigated as well as efficiency in a small number of researches. In addition, research findings have shown that video model applications are effective in teaching skills such as social skills, play skills, language and communication skills, functional skills, self-care skills, and daily life skills.

Gül and Vuran (2010) studied researches teaching social skills with video model among the individuals with developmental disabilities between 2000-2008, and they reached 21 researches. Findings obtained within the scope of the research were examined by document analysis method. According to the information obtained from research findings, modeling with video practices have been shown to be effective in teaching social skills to individuals with developmental disabilities.

When researches, related to social skills training for individuals with intellectual disability in Turkey, is examined, it is observed that there are studies that be handled in a single technique, such as social story and video model, but in general there is no review study. Moreover, when the compiling studies are examined, it is seen that these studies are the analysis of the researches done with children with autism spectrum disorder. It is thought that this study will guide practitioners and researchers by examining basic categories such as research models used in social skills teaching, selected social skills for teaching, retention and generalization studies of taught social skills, social validity and reliability studies for individuals with intellectual disabilities. In addition, because of the efficacy studies are often preferred in field, it has been included among research criteria that the research to be determined for the study is designed according to single-study research models. In accordance with this requirement the aim of the work is a review of social skills training researches that held in Turkey between the years 2000-2017 and was designed as a single-subject research for individuals with intellectual disability.

\section{Method}

\section{Research Model}

This is a qualitative document analysis. Documents suitably collected while working in a particular area are a source of data (Patton, 2002). In this context, the research reports in the study have been analyzed in terms of revealing the nature of the studies on social skills teaching of individuals with intellectual disabilities. In the scope of the study, the researches about social skills education for individuals with intellectual disabilities were analyzed by descriptive analysis through descriptive summaries.

\section{Research Area}

In this study, articles in peer-reviewed journals and theses in Turkey regarding the social skills working with individuals with intellectual disability have been analyzed. As a result of this study, 13 studies have been reached. The following criteria were taken into consideration in the selected studies:

a) The research is concerned with the teaching of social skills to individuals with intellectual disabilities,

b) Single- subject research

c) Theses and articles are written in Turkey between the years 2000-2017.

\section{Data Collection}

In the process of scanning the research articles, electronic databases for scanning were used by the Google Scholar, Council of Higher Education Theses Center website and Abant İzzet Baysal University Library subscriber databases. To reach the researches to be investigated; the names of social skills such as 'social skills', 'social skills education', 'thanking' and 'greetings' were taken as key words and screened accordingly. In the scan results, researches to be used in the study, a) covering the 2000-2017 years, b) was published in Turkey, c) carried out a 
social skills training to individuals with intellectual disability, d) studies using single-subject research method are chosen. 13 studies were identified for the study according to the determined criteria.

\section{Data Analysis}

The researches in the research area are numbered. Then, by researchers, the following characteristics were determined: a) the characteristics of the subjects, b) the dependent variable, c) the independent variable, d) the research design, e) the environment, f) monitoring and generalization, g) reliability, h) social validity and 1) findings category. The data related to each category were analized processing into the created table. The table contains eight columns that contain information about each category. The researchers read the researches and got detailed notes according to the categories. The data obtained in all categories are written in detail. The comments of the researchers were discussed in the discussion section of this work, supported by references.

\section{Intercoder Reliability}

The reliability study related to the descriptive analysis process was carried out by evaluating all of the selected researches in detail within the determined criteria by the second and third authors of the researcher who made master studies in the field of education of the intellectual disability and were doing doctorate in the same field using the research evaluation form. Intercoder Reliability calculation was performed using the formula [consensus / (consensus + dissent) x 100], and intercoder reliability was determined as $100 \%$.

\section{Findings}

As a result of the source survey 13 researches were examined. The research data covered in this study are tabulated according to the categories examined. Findings obtained in these categories have been reported in detail along with the findings on the tablature. A brief analysis of research on social skills teaching for individuals with intellectual disabilities is shown in Table 1. 
Table 1. Single-Subject Investigations in the Field of Teaching Social Skills for Individuals with Intellectual Disabilities

\begin{tabular}{|c|c|c|c|c|c|c|c|c|c|}
\hline Source & $\begin{array}{l}\text { Properties } \\
\text { of Subjects } \\
\text { M / F: } \\
\text { Number } \\
\text { (Age) }\end{array}$ & Dependent variable & $\begin{array}{c}\text { Independent } \\
\text { variable }\end{array}$ & Research Design & Environment & $\mathbf{M} / \mathbf{G}$ & IR/AR & SV & Results \\
\hline $\begin{array}{l}\text { Alptekin, } \\
\text { S. } \\
2010\end{array}$ & $\begin{array}{l}\text { Intellectual } \\
\text { disability } \\
\text { M: } 1(11)\end{array}$ & $\begin{array}{l}\text { Thank, help, } \\
\text { asking a } \\
\text { permission }\end{array}$ & $\begin{array}{l}\text { Direct } \\
\text { teaching } \\
\text { with peer } \\
\text { models }\end{array}$ & $\begin{array}{l}\text { Multiple probe } \\
\text { design with } \\
\text { probe trials } \\
\text { across behaviors }\end{array}$ & Library & $\mathrm{Y} / \mathrm{Y}$ & $\mathrm{N} / \mathrm{Y}$ & $\mathrm{Y}$ & $\begin{array}{l}\text { As a result of the research, teaching with } \\
\text { direct teaching approach by using peer } \\
\text { models is influential in the attainment of } \\
\text { the targeted behaviors and in the } \\
\text { sustainment and generalization of the } \\
\text { achievements. }\end{array}$ \\
\hline $\begin{array}{l}\text { Avcioğlu, } \\
\text { H. } \\
2012-\mathrm{a}\end{array}$ & $\begin{array}{l}\text { Intellectual } \\
\text { disability } \\
\text { M:2 (8), } \\
\mathrm{F}: 1(8)\end{array}$ & $\begin{array}{l}\text { Introducing } \\
\text { yourself }\end{array}$ & Drama & $\begin{array}{l}\text { Multiple probe } \\
\text { design with } \\
\text { probe trials } \\
\text { across subjects }\end{array}$ & Game room & $\mathrm{Y} / \mathrm{Y}$ & $\mathrm{Y} / \mathrm{Y}$ & $\mathrm{N}$ & $\begin{array}{l}\text { As a result of the research, it was seen that } \\
\text { children with intellectual disability can } \\
\text { acquire, promote and generalize their self- } \\
\text { promotion skills to their peers at the school } \\
\text { for free play activities. }\end{array}$ \\
\hline $\begin{array}{l}\text { Avcioğlu, } \\
\text { H. } \\
2012-b\end{array}$ & $\begin{array}{l}\text { Intellectual } \\
\text { disability } \\
\text { M:5 (10- } \\
\text { 12), } \\
\text { F:4 (10-12) }\end{array}$ & Self-control & $\begin{array}{l}\text { Self- } \\
\text { management } \\
\text { strategy }\end{array}$ & $\begin{array}{l}\text { Multiple probe } \\
\text { design with } \\
\text { probe trials } \\
\text { across subjects }\end{array}$ & Game room & $\mathrm{Y} / \mathrm{Y}$ & $\mathrm{Y} / \mathrm{Y}$ & $\mathrm{N}$ & $\begin{array}{l}\text { Research findings; self-management } \\
\text { strategies and the teaching package } \\
\text { presented by the intellectual disabity } \\
\text { students demonstrate that they are effective } \\
\text { in proving their anger without harming } \\
\text { others, solving the differences by talking } \\
\text { about differences and solving their } \\
\text { problems without fighting others, and } \\
\text { using these skills after the end of practice. }\end{array}$ \\
\hline
\end{tabular}


The Review of Single Subject Researches in the Field

\begin{tabular}{|c|c|c|c|c|c|c|c|c|c|}
\hline Source & $\begin{array}{c}\text { Properties } \\
\text { of Subjects } \\
\text { M / F: } \\
\text { Number } \\
\text { (Age) }\end{array}$ & Dependent variable & $\begin{array}{l}\text { Independent } \\
\text { variable }\end{array}$ & Research Design & Environment & M/G & IR/AR & SV & Results \\
\hline $\begin{array}{l}\text { Avcıŏlu, } \\
\text { H. } \\
2013\end{array}$ & $\begin{array}{l}\text { Intellectual } \\
\text { disability } \\
\text { M: } 2(11- \\
\text { 12), } \\
\mathrm{F}: 1 \text { (12) }\end{array}$ & Greeting & Video model & $\begin{array}{l}\text { Multiple probe } \\
\text { design with } \\
\text { probe trials } \\
\text { across subjects }\end{array}$ & $\begin{array}{l}\text { Individual } \\
\text { education } \\
\text { class }\end{array}$ & $\mathrm{Y} / \mathrm{Y}$ & $\mathrm{Y} / \mathrm{Y}$ & $\mathrm{Y}$ & $\begin{array}{l}\text { Research findings; the video shows that } \\
\text { students with intellectual disabilities in } \\
\text { teaching as a result of the model have } \\
\text { gained and sustained the ability to say } \\
\text { hello and are developed in different } \\
\text { environments and persons. }\end{array}$ \\
\hline $\begin{array}{l}\text { Çadır, D. } \\
2008\end{array}$ & $\begin{array}{l}\text { Intellectual } \\
\text { disability } \\
\text { M:7 (10- } \\
11) \\
\text { F:2 (11) }\end{array}$ & $\begin{array}{l}\text { Inviting others to } \\
\text { play games, } \\
\text { bringing back the } \\
\text { stuff from others, } \\
\text { fulfillment of the } \\
\text { task }\end{array}$ & $\begin{array}{l}\text { Music } \\
\text { therapy }\end{array}$ & $\begin{array}{l}\text { Multiple probe } \\
\text { design with } \\
\text { probe trials } \\
\text { across subjects }\end{array}$ & Class & $\mathrm{N} / \mathrm{Y}$ & $\mathrm{Y} / \mathrm{Y}$ & $\mathrm{Y}$ & $\begin{array}{l}\text { At the end of this study, the students with } \\
\text { intellectual disabilities who participated in } \\
\text { the research have used the social skills } \\
\text { teaching program prepared based on the } \\
\text { music therapy method and supported by } \\
\text { the music activities, the aimed skills to be } \\
\text { taught and the impression that the music } \\
\text { therapy teaching method is effective. }\end{array}$ \\
\hline $\begin{array}{l}\text { Çadır, D. } \\
\text { Avcıoğlu, } \\
\text { H. } \\
2013\end{array}$ & $\begin{array}{l}\text { Intellectual } \\
\text { disability } \\
\text { M:5 (10- } \\
11) \\
\text { F:4 (10-11) }\end{array}$ & $\begin{array}{l}\text { Invite others to } \\
\text { play games, } \\
\text { bringing back the } \\
\text { stuff from others, } \\
\text { fulfillment of the } \\
\text { task }\end{array}$ & $\begin{array}{l}\text { Music } \\
\text { therapy }\end{array}$ & $\begin{array}{l}\text { Multiple probe } \\
\text { design with } \\
\text { probe trials } \\
\text { across subjects }\end{array}$ & Class & $\mathrm{Y} / \mathrm{Y}$ & $\mathrm{Y} / \mathrm{Y}$ & $\mathrm{Y}$ & $\begin{array}{l}\text { Findings of research; the teaching package } \\
\text { presented with the music therapy method } \\
\text { shows that the students with intellectual } \\
\text { disability are effective in the acquisition of } \\
\text { the target skills and that the students who } \\
\text { gain these skills continue to use these skills } \\
\text { after the end of practice. }\end{array}$ \\
\hline
\end{tabular}


Sönmez, Karabulut, Kot, \& Tekinarslan

\begin{tabular}{|c|c|c|c|c|c|c|c|c|c|}
\hline Source & $\begin{array}{c}\text { Properties } \\
\text { of Subjects } \\
\text { M / F: } \\
\text { Number } \\
\text { (Age) }\end{array}$ & Dependent variable & $\begin{array}{l}\text { Independent } \\
\text { variable }\end{array}$ & Research Design & Environment & $\mathbf{M} / \mathbf{G}$ & IR/AR & SV & Results \\
\hline $\begin{array}{l}\text { Çakır, S. } \\
2006\end{array}$ & $\begin{array}{l}\text { Intellectual } \\
\text { disability } \\
3(17-18)\end{array}$ & $\begin{array}{l}\text { Talking on the } \\
\text { phone }\end{array}$ & $\begin{array}{l}\text { Direct } \\
\text { instruction }\end{array}$ & $\begin{array}{l}\text { Multiple probe } \\
\text { design across } \\
\text { subjects }\end{array}$ & - & $\mathrm{Y} / \mathrm{Y}$ & $\mathrm{Y} / \mathrm{Y}$ & $\mathrm{Y}$ & $\begin{array}{l}\text { According to the findings obtained in the } \\
\text { research, telephone conversation social } \\
\text { skills education prepared by direct } \\
\text { teaching approach has been effective in the } \\
\text { achievement and maintenance of three } \\
\text { students in the research. }\end{array}$ \\
\hline $\begin{array}{l}\text { Çelik, H. } \\
2010\end{array}$ & $\begin{array}{l}\text { Intellectual } \\
\text { disability } \\
\text { M: } 2(12), \\
\text { F:4 (10-12) }\end{array}$ & $\begin{array}{l}\text { Self-control, } \\
\text { coping with } \\
\text { aggressive } \\
\text { behavior }\end{array}$ & $\begin{array}{l}\text { Self- } \\
\text { management } \\
\text { strategy }\end{array}$ & $\begin{array}{l}\text { Multiple probe } \\
\text { design with } \\
\text { probe trials } \\
\text { across subjects }\end{array}$ & Class & $\mathrm{Y} / \mathrm{Y}$ & $\mathrm{Y} / \mathrm{Y}$ & $\mathrm{Y}$ & $\begin{array}{l}\text { According to the findings of the research, } \\
\text { it was determined that the social skill } \\
\text { curriculum based on the self-management } \\
\text { technique was effective in acquiring the } \\
\text { target social skills and generalizations of } \\
\text { the students with six intellectual } \\
\text { disabilities participating in the research. }\end{array}$ \\
\hline $\begin{array}{l}\text { Çifci, İ. } \\
2001\end{array}$ & $\begin{array}{l}\text { Intellectual } \\
\text { disability } \\
\text { M: } 5(15- \\
\text { 16) } \\
\text { F: } 4 \text { (16- } \\
\text { 19) }\end{array}$ & $\begin{array}{l}\text { Apologize, coping } \\
\text { with ridicule, } \\
\text { avoiding } \\
\text { inappropriate } \\
\text { touching }\end{array}$ & $\begin{array}{l}\text { Cognitive } \\
\text { process } \\
\text { approach }\end{array}$ & $\begin{array}{l}\text { Multiple probe } \\
\text { design with } \\
\text { probe conditions } \\
\text { across subjects }\end{array}$ & Class & $\mathrm{N} / \mathrm{Y}$ & $\mathrm{Y} / \mathrm{Y}$ & $\mathrm{N}$ & $\begin{array}{l}\text { As a result of the research, it was seen that } \\
\text { the social skills curriculum based on the } \\
\text { cognitive process approach was effective } \\
\text { in acquiring the target social skills and } \\
\text { generalizing these skills of a total of nine } \\
\text { intellectual disability learners. }\end{array}$ \\
\hline
\end{tabular}




\begin{tabular}{|c|c|c|c|c|c|c|c|c|c|}
\hline Source & $\begin{array}{c}\text { Properties } \\
\text { of Subjects } \\
\text { M / F: } \\
\text { Number } \\
\text { (Age) } \\
\end{array}$ & Dependent variable & $\begin{array}{l}\text { Independent } \\
\text { variable }\end{array}$ & Research Design & Environment & $\mathbf{M} / \mathbf{G}$ & IR/AR & SV & Results \\
\hline $\begin{array}{l}\text { Dağseven } \\
\text { Emecen, } \\
\text { D. } \\
2011\end{array}$ & $\begin{array}{l}\text { Epilepsy, } \\
\text { Intellectual } \\
\text { disability } \\
\text { M:1 (13), } \\
\text { F:1 (11) }\end{array}$ & Thanking, sharing & $\begin{array}{l}\text { Direct } \\
\text { instruction, } \\
\text { Cognitive } \\
\text { process } \\
\text { approach }\end{array}$ & $\begin{array}{l}\text { Alternating } \\
\text { conditions model }\end{array}$ & $\begin{array}{l}\text { Individual } \\
\text { education } \\
\text { class }\end{array}$ & $\mathrm{Y} / \mathrm{Y}$ & $\mathrm{Y} / \mathrm{Y}$ & $\mathrm{Y}$ & $\begin{array}{l}\text { According to the findings obtained in the } \\
\text { research, it is observed that the direct } \\
\text { teaching approach is more effective in } \\
\text { giving social skills to a one-way trial and } \\
\text { the similar effect is in two-way trial. } \\
\text { Achieving social skills has been achieved } \\
\text { as a result of the fact that the direct } \\
\text { teaching approach is more efficient in } \\
\text { terms of the total duration of teaching and } \\
\text { the number of wrong responses. }\end{array}$ \\
\hline $\begin{array}{l}\text { Özokçu, } \\
\text { O. } \\
2008\end{array}$ & $\begin{array}{l}\text { Intellectual } \\
\text { disability } \\
\text { M: } 1(12) \\
\text { F: } 2(11- \\
12)\end{array}$ & $\begin{array}{l}\text { Apologize, } \\
\text { asking for help, } \\
\text { finish a job on } \\
\text { time }\end{array}$ & $\begin{array}{l}\text { Direct } \\
\text { instruction }\end{array}$ & $\begin{array}{l}\text { Multiple probe } \\
\text { design with } \\
\text { probe conditions } \\
\text { across subjects }\end{array}$ & Source room & N/Y & $\mathrm{Y} / \mathrm{Y}$ & $\mathrm{Y}$ & $\begin{array}{l}\text { As a result of the research, it has been seen } \\
\text { that the social skills curriculum based on } \\
\text { the direct teaching approach is effective in } \\
\text { acquiring the target social skills of the } \\
\text { three mentally retarded students in total } \\
\text { and in generalizing these skills. }\end{array}$ \\
\hline $\begin{array}{l}\text { Sazak, E. } \\
2003\end{array}$ & $\begin{array}{l}\text { Intellectual } \\
\text { disability } \\
\text { F: } 1(9)\end{array}$ & $\begin{array}{l}\text { Introduce } \\
\text { introducing } \\
\text { yourself, asking } \\
\text { for help or } \\
\text { information, share }\end{array}$ & $\begin{array}{l}\text { Peer- } \\
\text { mediated } \\
\text { teaching }\end{array}$ & $\begin{array}{l}\text { Multiple probe } \\
\text { design with } \\
\text { probe trials } \\
\text { across behaviors }\end{array}$ & $\begin{array}{l}\text { Guidance } \\
\text { Research } \\
\text { Center test } \\
\text { room }\end{array}$ & $\mathrm{Y} / \mathrm{N}$ & $\mathrm{Y} / \mathrm{Y}$ & $\mathrm{N}$ & $\begin{array}{l}\text { At the end of the research, peer-mediated } \\
\text { social skills curriculum has been found to } \\
\text { be effective in acquiring self-promotion, } \\
\text { help or information seeking and sharing } \\
\text { skills targeted at student learning. }\end{array}$ \\
\hline
\end{tabular}


Sönmez, Karabulut, Kot, \& Tekinarslan

\begin{tabular}{|c|c|c|c|c|c|c|c|c|c|}
\hline Source & $\begin{array}{c}\begin{array}{c}\text { Properties } \\
\text { of Subjects } \\
\text { M / F: } \\
\text { Number } \\
\text { (Age) }\end{array} \\
\end{array}$ & Dependent variable & $\begin{array}{l}\text { Independent } \\
\text { variable }\end{array}$ & Research Design & Environment & $\mathbf{M} / \mathbf{G}$ & IR/AR & SV & Results \\
\hline $\begin{array}{l}\text { Türer, H. } \\
2010\end{array}$ & $\begin{array}{l}\text { Intellectual } \\
\text { disability } \\
\text { M: } 2(7), \\
\text { F:1 (8) }\end{array}$ & Thank, apologize, & $\begin{array}{l}\text { Direct } \\
\text { instruction }\end{array}$ & $\begin{array}{l}\text { Multiple probe } \\
\text { design with } \\
\text { probe trials } \\
\text { across subjects }\end{array}$ & $\begin{array}{l}\text { Individual } \\
\text { education } \\
\text { class }\end{array}$ & $\mathrm{Y} / \mathrm{Y}$ & $\mathrm{N} / \mathrm{N}$ & $\mathrm{N}$ & $\begin{array}{l}\text { According to the results obtained from the } \\
\text { research, it was observed that the direct } \\
\text { teaching method was effective in the } \\
\text { success of the three students in acquiring } \\
\text { the skills of acknowledging and } \\
\text { apologizing, generalizing to different } \\
\text { environments, persons and objects, and } \\
\text { continuing } 7,21 \text { and } 35 \text { days after } \\
\text { teaching. }\end{array}$ \\
\hline
\end{tabular}

M: Male, F: Female, M: Maintance, G: Generalization, IR: Interobserver Reliability, AR: Application Reliability, SV: Social Validity, Y: Yes, N: No 


\section{Dependent and independent variables}

In the researches, it was seen that the skills of coping with ridicule, avoiding inappropriate touching, thanking, sharing, inviting others to play games, bringing back the stuff they took from others, performing the tasks they undertake, introducing yourself, self-control, greeting, asking for help or information, participating in activities, coping with aggressive behaviors, apologizing, helping and asking for permission were selected as dependent variables. Direct instruction, music therapy, drama, self-management strategy, video modeling, peer mediated social skills teaching program, social story and peer models using direct instruction methods and strategies were used as independent variables and the effects of independent variables on dependent variables were examined.

\section{The subjects}

The subjects in the investigated studies were examined by considering the variables a) age, and b) sex. Demographic information about the subjects is given in Table 2.

Table 2. Demographic Information of Subjects

\begin{tabular}{clc}
\hline \multicolumn{1}{c}{ Variables } & Frequency \\
\hline \multirow{2}{*}{ Age } & $7-11$ & 40 \\
& $12-19$ & 21 \\
\multirow{2}{*}{ Gender } & Female & 25 \\
& Male & 33 \\
\hline
\end{tabular}

A total of 61 subjects were included in the study, 40 of the subjects were in the 7-11 age range, and 21 were in the 12-19 age range. 25 of the subjects were girls and 33 were males. There are 3 subjects without sex. Besides, 8 normal development individuals in the researches also helped researchers in teaching.

\section{Research designs}

In this study, one of the criteria in the study of determining the investigations is the use of single-subject experimental designs. In this respect, Table 3 contains the single-subject experimental designs used in the research.

Table 3. Single Case Designed Used in Research

\begin{tabular}{lc}
\hline \multicolumn{1}{c}{ Variables } & Frequency \\
\hline Multiple probe design with probe trials across subjects & 7 \\
Multiple probe design with probe conditions across subjects & 2 \\
Multiple probe design with probe trials across behaviors & 2 \\
Alternating conditions model & 1 \\
\hline
\end{tabular}

When the Table 3 is examined, it is seen that the most used single-subject experimental design is multiple probe design with probe trials (9), and this model is mostly carried out across the subjects (7).

The second most commonly used single-subject experimental design is multiple probe design with probe conditions (2), and also this model is mostly carried out across the subjects (2). In one study, it was determined that alternating conditions model were used.

\section{Maintance and Generalization}

In the vast majority of investigations (10), it was seen that the maintance process was planned and the data related to this process were collected. Maintance level data collection form was used in the researches. Maintance data were collected after 1, 3, and 4 weeks of instruction, and the longest follow-up data was collected 35 days after instruction. When we examined from the point of generalization, it was seen that most of the investigated studies (12) collected setting, tools and personal generalizations.

\section{Interobserver Reliability, Procedural Reliability and Social Validity}

It has been determined that only one of the investigations related to the social skills studies of the individuals with intellectual disabilities collected the interobserver reliability and the other collected interobserver reliability and procedural reliability data.

Social validity data were gathered in 8 of the researches on social skill studies of individuals with intellectual disabilities. Social validity data were obtained from teachers in general through subjective evaluation. Teachers 
initially expressed their opinions by assessing if it is necessary for the students when determining the targeted social skills to be taught. The targeted skills are taught by class teachers who know their students. In two of the researches (Çadır, 2008; Dağseven-Emecen, 2011), social validity data were collected with the "Social Validity Form" prepared by the researchers. In one of these studies, there are chapters consisting of the aim section and ten questions, in which the questions will be marked as Yes I think (), No I do not () and Undecided (). In another research (Çadır, 2008), the skills to be taught within the scope of the research were determined by the teachers who best know the students and the Social Validity Form was prepared by the researcher. Avcioğlu (2012-b) and Avcioğlu (2013) watched the last video recording of the research with their parents and teachers. To assess the appropriateness of the findings obtained later, he collected social validity data by taking opinions from the students' mothers and teachers.

\section{Discussion and Conclusion}

In this study, 13 researches on social skills training for individuals with intellectual disabilities were examined and analyzed according to the determined criteria. The findings of each category were discussed in this section.

Researches on teaching social skills to students with intellectual disabilities were mostly carried out by individuals in the last childhood group at 7-11 years of age. It is observed that the individuals in adolescence after the last childhood group also participated in the researches (Avcıoğlu, 2012-b, Avcıoğlu, 2013, Çakır, 2006, Çelik, 2010, Çifci, 2001, Dağseven-Emecen, 2011, Özokçu, 2008). Social skills are skills that need to be taught starting from early ages, such as self-care skills. It is thought that these skills need to be acquired both in younger ages and in older ages. It is known that these skills are acquired through coincidental means, such as observation and imitation, in children without inadequacy. The limitations of imitation skills of individuals with intellectual disabilities make it necessary to teach these skills. Social skills are important to acquire at a young age, in addition to this, the social skills that need to be learned depend on age (Çolak, 2007). In this study, it is seen that social skills are provided to intellectual disability children who have more recent childhood and adolescence period. When the studies evaluated within the scope of the study were examined, it was determined that they did not work with individuals during early childhood and young adulthood.

Social skills have been categorized differently by several researchers. Although differently categorized, in the studies, it seems that interaction skills and interpersonal skills such as thanking, sharing, apoligizing, helping, asking for helping, asking for permission, talking to someone on the phone, inviting others to play games, bringing back the stuff they got from others, performing the task they are undertaking, self-control, coping with behaviors, introducing oneselfare gained. The selected social skills need to be selected for the child and the child's inadequacy in social skills teaching (Avcioğlu, 2007). In these surveys, the chosen social skills are the skills that children can use in the social environment outside of school and in the school. it is believed that research done for this reason is important for individuals with intellectual disabilities. In three studies conducted in Turkey, with the ability to cope with aggressive behavior and coping with ridicule is noteworthy. It is known that the frequency of violence and the incidence of bullying in schools has increased in recent years, and that many students have also faced such incidents. It is thought that if individuals with intellectual disabilities are also exposed to violence and bullying like every individual, it is thought that it is extremely important to gain such skills and that the number of such investigations should be increased.

Direct instruction method, self management strategy, peer education, music therapy method, cognitive process approach, video modeling, and drama method were used in the teaching of social skills in the researches investigated in this study. Only one of the researches (Dağseven-Emecen, 2011) included comparison of the methods. It has been seen that the methods and techniques mentioned here are effective in teaching target skills. However, researches that have been done recently show that there are more evidence-based applications. Increasing the number and spread of evidence-based practices for individuals with intellectual disabilities will enable us to better see the positive impact of the development of children with the inadequacy of the applied curriculum and instruction.

When we look at the researches examined within the scope of this study, it is seen that multiple probe designs with trial from the single subject designs are used extensively. In the meta-analysis of Bellini and Akullian (2007), 23 single-tasked studies of social skills teaching practices of autistic children and adolescents with a video model were investigated by calculating the percentage of non-overlapping data. The researches were conducted between 1987 and 2005. A total of 73 subjects aged between 3 and 20 years participated in these studies. Twenty-two of the 23 researches were performed using multiple baseline or multiple probe designs. One research used reversal 
design. Only multiple baseline design was used in 16, multiple baseline and changing conditions model were used in 3, multiple baseline and alternating treatment design were used in 2, multiple baseline and reversal design of the 22 researches using multiple baseline or multiple probe designs.

In the researches investigated, it was reached that the follow-up period was planned and interest data were gathered in the process. When the findings of the researches are examined, separate monitoring level data collection form is prepared for social skills. The data collection form was created by the researcher in accordance with the purpose of each research. In all of the studies it has been seen that the participants retained the skills they acquired after teaching and these skills were developed into different environments, people and tools. This finding suggests that the importance given to generalization and retention studies in our country is increasing. The generalization of the learned skill or behavior to the environments outside the teaching, to the persons, to the stimuli enables the individual to reinforce in the natural events and to interact positively with the environment (Tekin-İftar and Kircaali-İftar, 2001).

When researches are examined, it is seen that social validity data are not collected in 5 out of 13 studies. In a study that does not include social validity data, it is seen that social validity data are not collected, and it is seen that, in the advanced researches, the children who participated in the research are offered the suggestion of collecting social validity data from themselves, their parents and teachers. The social validity of the researches investigated was determined by examining whether the social skills targeted primarily for the students are necessary for the students. When evaluating an application, it is not sufficient to consider whether the application is only effective. It is also necessary to question the dimensions of the social significance of whether the method used is applied in a practical way, whether the method is worth applying, whether the applied individuals are satisfied with the change in behavior attained and whether the output obtained results in a meaningful change in the quality of life of the individuals. In this context, it is very important that social validity data are gathered in teaching practices that are carried out in order to gain new social skills to individuals with intellectual disabilities and to use these social skills in society. It is seen that the social validity data are collected mainly in the recent years in our country (Avcıoğlu, 2012-a, Avcıoğlu, 2013, Çadır, 2008, Çelik, 2010, Emecen, 2008). This is an indication that the importance given to social justice is increasing.

When the researches are examined in terms of reliability data, application reliability data and interobserver reliability data are collected in the majority of the studies. This suggests that all of the researches investigated are carried out as planned. Also, the fact that the reliability data are collected removes the question marks about the application phases of the research.

This study aimed to examine the published articles and graduate and doctoral theses published in peer-reviewed journals in Turkey for teaching social skills to work with individuals with intellectual disability. To this end, studies involving individuals with intellectual disabilities using social skills training with single-subject experimental designs between 2000 and 2017 were included. In the study, informations were given about teaching social skills to individuals with intellectual disabilities and tried to investigate researches on social skills teaching for individuals with intellectual disabilities. Although the study is limited to 13 studies, containing articles, master's and doctoral theses published between the years 2000-2017 in Turkey, on teaching social skills, which are designed as single-subject research for individuals with intellectual disabilities, it is thought that the study will contribute to the literature and the researcher. If one of the important limitations of individuals with intellectual disabilities is considered to be social skills, it can be said that the studies carried out in this area are few and that the individuals with intellectual disability should attach importance to this field in order to live a better life.

From this study, in further researches, it is suggested to carry out the followings: (a) researches on the use of different experimental methods for individuals with intellectual disabilities, (b) research on social skills teaching involving individuals in different groups of disabilities and (c) to carry out researches that can be examined comparatively. 


\section{Türkiye'de Zihin Yetersizliği Olan Bireylerle Sosyal Beceri Öğretimi Alanında Gerçekleştirilen Tek Denekli Araştırmaların İncelenmesi}

\section{Giriş}

Eğitimde bütün bireyler için hedeflenen amaç, bireylerin toplum içerisinde bağımsız bir yaşam sürdürebilmelerini sağlamaktır (Snell ve Brown, 2011). Özel gereksinimli bireyler için de eğitimin temel amac1, onların toplum içerisinde bağımsız ya da en az bağımlı olarak yaşamlarını sürdürmelerini ve toplumun beklentilerini yerine getirebilmelerini sağlamak, yani onları toplumsal yaşama hazırlamak için gerekli olan becerileri kazandırmaktır (Çifci ve Sucuoğlu, 2005; Dağseven-Emecen, 2011). Bireylerin bağımsız olarak yaşamlarını sürdürebilmeleri, özbakım, iletişim, akademik ve iş becerilerine bağlı olduğu gibi kurdukları kişiler arası ilişkilere de bağlıdır (Çifci ve Sucuoğlu, 2005). Bireyler, kişiler arası ilişkilerde başarılı olmalarını sağlayan davranışları ortaya koyabilmeleri için sosyal becerilere gereksinim duymaktadırlar (Avcığlu, 2005). Sosyal beceri, bireylerin yaşamlarını bağımsız ve toplumla uyum içinde sürdürmesini sağlayan ve bireyin yaşam kalitesini doğrudan etkileyen davranışları ifade etmektedir (Mercer ve Mercer, 2005). Sosyal beceriler toplumsal yaşamın ayrılmaz bir parçasıdır. Bu nedenle sosyal beceriler insan yaşamında çok önemli bir role sahiptir (Bacanlı, 1999). İnsanlar bebeklikten başlayarak birçok sosyal beceriyi yakın çevrelerindeki bireylerden yani anne-babalarından, kardeşlerinden ve akranlarından öğrenmektedirler.

Normal gelişim gösteren bireyler sosyal becerileri aile, arkadaş ve yetişkinlerin model olması ve gözlem yoluyla sistematik olmayan bir biçimde öğrenebilirlerken, zihin yetersizliği olan bireylerde sosyal becerilerin edinimi bu şekilde gerçekleşmemekte, bir öğretim süreci gerekmektedir (Avcioğlu, 2005). Zihin yetersizliği olan bireylerin sosyal becerileri edinmede yaşadıkları zorluklar bu bireylerin toplumla bütünleşmelerini güçleştirmekte ve akran etkileşimlerini olumsuz etkilemektedir. Sosyal becerilerin öğretilmesi, bu olumsuzlukların giderilmesini sağlayacak, böylece bireylerin yaşam kalitesinin arttırılmasına hizmet edecektir (Avcıoğlu, 2012-a). Bu noktada sosyal becerilerin nasıl kazandırılabileceği sorusu gündeme gelmektedir. Sosyal becerilerin öğretiminde pek çok farklı yöntem ve teknikten yararlanılabilmektedir. Alanyazın incelendiğinde, model olma (Odluyurt, 2013), videoyla model olma (Acar, 2015; Avcıŏlu, 2013; Emecen, 2008; Scattone, 2008; Sansosti ve Powell-Smith, 2008; Paterson ve Arco, 2007), şekil verme, davranışsal prova ve rol oynama (Akfırat, 2004; Avcıoğlu, 2012-b; Eldeniz, 2005; İpek, 1998), doğrudan öğretim (Alptekin, 2010; Çakır, 2006; Özokçu, 2008), bilişsel süreç yaklaşımı (Çifci, 2001; Emecen, 2008), işbirliğine dayalı öğrenme (Avcıŏlu, 2001; Avcıŏlu, 2012-a), kendini yönetme (Avcıoğlu, 2012-b; Çelik, 2010) ve temel tepki öğretiminin (Harper vd., 2008; Pierce ve Schreibman, 1995, 1997) kullanıldığı araştırmaların bulunduğu görülmektedir. Alanyazında yapılan araştırmalarda sosyal becerileri öğretiminin zihin yetersizliği olan bireylerin toplum içerisinde bağımsız yaşamlarını sürdürebilmeleri yönünden olumlu sonuçlar sağladığı ifade edilmektedir (Türer, 2010; Dağseven-Emecen, 2011; Alptekin, 2012; Avcioğlu, 2012-a, 2012-b; Alptekin ve Özyürek, 2013).

Pek çok araştırmada zihin yetersizliği olan bireylerle yapılan çalışmaların bireylere olumlu sonuçlar sağladığ ifade edilmektedir. Fakat zihin yetersizliği olan bireylerle yapılan çalışmalarda kullanılan yöntemlerin bilimsel dayanaklı olması gerektiği, hatta bunun bazı yasalarla zorunluluk haline dönüştürüldüğü uzmanlar tarafından vurgulanmaktadır (Horner vd., 2005; Odom vd., 2005). Zihin yetersizliği olan bireylerin toplumda bağımsız yaşamaları için sosyal beceri öğretiminin olumlu sonuçlarını ortaya koymak adına bilimsel dayanaklı uygulamalara yer verilmesi gerektiği düşünülmektedir (Yücesoy-Özkan ve Sönmez, 2011). Bilimsel dayanaklı uygulamalar, yeterli miktarda araştırma bulgusu olan ve bulgular sonucunda etkili olduğunu gösteren uygulamalardır. Bu uygulamaları belirlemek için atılacak en temel adım meta-analiz çalışmaları yapmaktır (Yücesoy-Özkan ve Sönmez, 2011). Alanyazın incelendiğinde zihin yetersizliği olan bireylere sosyal beceri öğretimi ile ilgili betimsel ve meta-analizi çalışmalarının yapıldığg görülmektedir.

Bellini vd. (2007) tarafından gerçekleştirilen ve 1986-2005 yılları arasında yayınlanan 55 makalenin incelendiği bir meta-analizi çalışmasında öğretim, kalıcılık ve genellemenin etki büyüklüğü belirlenmeye çalışılmıştır. Çalışmanın amacı otizm spektrum bozukluğu olan öğrenciler için okul temelli sosyal beceri öğretimi üzerine çalışılmış tek denekli araştırmaların sentezini yapmaktır. Çalışmanın diğer bir amacı da katılımcı özelliklerini, uygulama özelliklerini ve araştırma çıktılarını bir araya getirerek otizm spektrum bozukluğu olan bireyler için en etkili öğretim yöntemini ortaya koymaktır. Bu çalışmanın sonuçlarına göre sosyal beceri öğretimi otizm spektrum bozukluğu olan bireyler için sınırlı etkiye sahiptir. Bireyler öğrendikleri becerileri genellemekte 
zorluk yaşamaktadırlar. En düşük kalıcılığın okul öncesi dönemde, en düşük genellemenin de ilkokul dönemlerindeki bireylerde olduğu gözlemlenmiştir.

Sani Bozkurt ve Vuran (2014) tarafindan dünyada ve Türkiye'de 1991-2011 yılları arasında yayınlanmış otizm spektrum bozukluğu olan bireylere sosyal becerilerin öğretiminde sosyal öykülerin kullanıldığı 22 araştırma incelenmiştir. Araştırmanın amacı otizm spektrum bozukluğu olan çocuklara sosyal beceri öğretiminde sosyal öykülerin kullanıldığı çalışmaları analiz etmektir. Bu çalışma tek denekli araştırmaların betimsel ve meta-analizini içermektedir. Araştırma bulgularından elde edilen sonuçlara göre sosyal öykülerin OSB'li bireylere sosyal beceri öğretmek için kanıt temelli bir uygulama olarak henüz düşünülmemesi gerektiğini göstermektedir. Ancak sosyal öykülerin ileri araştırmalar için umut verici olduğu düşünülmektedir.

Acar ve Diken (2012) tarafından gerçekleştirilen alan yazın taramasında dünyada ve Türkiye'de yapılmış, 2000-2010 yıllarını kapsayan, otizm spektrum bozukluğu olan bireylere çeşitli becerilerin öğretiminde video model yönteminin kullanıldığı 31 araştırma incelenmiştir. Araştırmada, video model uygulamalarının etkililiği hakkında alanda çalışan öğretmen ve uzmanları bilgilendirmek amaçlanmıştır. Araştırma kapsamındaki çalışmalar betimsel özetlemeler yoluyla betimsel analiz kullanılarak incelenmiştir. Araştırma bulgularından elde edilen sonuçlara göre, incelenen araştırmalarda hedeflenen becerilerin öğrenilmesinde yöntemin etkililiğine bakılırken, çok az sayıda araştırmada etkililiğin yanı sıra verimlilik de incelenmiştir. Ayrıca araştırma bulguları video model uygulamalarının sosyal beceriler, oyun becerileri, dil ve iletişim becerileri, işlevsel beceriler, öz-bakım becerileri, günlük yaşam becerileri gibi becerilerin öğretiminde etkili olduğunu göstermiş̧tir.

Gül ve Vuran (2010), 2000-2008 yılları arasında, gelişimsel yetersizlik gösteren bireylere video model ile sosyal beceri öğretimi yapan araştırmaları taramışlar ve 21 araştırmaya ulaşmışlardır. Araştırma kapsamında elde edilen bulgular doküman analizi yöntemiyle incelenmiş̧ir. Araştırma bulgularından elde edilen bilgilere göre, video ile model olma uygulamalarının gelişimsel yetersizlik gösteren bireylere sosyal beceri öğretiminde etkili olduğu görülmüştür.

Türkiye'de zihin yetersizliği olan bireylere yönelik sosyal beceri öğretimi ile ilgili gerçekleştirilen araşstırmalar incelendiğinde sosyal öykü, video model gibi tek bir tekniğin ele alınıp incelendiği çalışmaların var olduğu fakat genel anlamda bir gözden geçirme çalışmasının bulunmadığı görülmektedir. Ayrıca yapılan derleme çalışmaları incelendiğinde de bu araştırmaların otizm spektrum bozukluğu tanısı olan çocuklarla yapılan araştırmaların analizi olduğu görülmektedir. Bu çalışmanın, zihin yetersizliği olan bireylere sosyal beceri öğretiminde kullanılan araştırma modelleri, öğretim için seçilen sosyal beceriler, öğretilen sosyal becerilerin kalıcılık ve genelleme çalışmaları, sosyal geçerlik ve güvenirlik çalışmaları gibi temel kategoriler açısından incelenmesi ile uygulamacılara ve araştırmacılara rehberlik edeceği düşünülmektedir. Ayrıca alanda sıklıkla etkililik çalışmalarının tercih edilmesinden dolayı, araştırma için belirlenecek olan araştırmaların tek denekli araştırma modellerine göre desenlenmiş olması araştırma ölçütleri arasında alınmıştır. Bu gereksinim doğrultusunda çalışmanın amacı, 2000-2017 yılları arasında Türkiye'de gerçekleştirilen, zihin yetersizliği olan bireylere yönelik tek denekli araştırma olarak desenlenen, sosyal beceri öğretimi araştırmalarının gözden geçirilmesidir.

\section{Yöntem}

\section{Araştırma Modeli}

Bu çalışma nitel bir doküman analizidir. Belli bir alanda çalışırken amaca uygun olarak toplanan dokümanlar birer veri kaynağıdır (Patton, 2002). Bu bağlamda çalışmada araştırma raporları, zihin yetersizliği olan bireylere sosyal beceri öğretimine ilişkin yapılan çalışmaların doğasını ortaya koymak açısından analiz edilmiştir. Çalışma kapsamında, zihin yetersizliği olan bireylere sosyal beceri öğretimi ile ilgili araştırmalar betimsel özetlemeler yoluyla betimsel analizle incelenmiştir.

\section{Araştırma Alanı}

$\mathrm{Bu}$ araştırmada zihin yetersizliği olan bireylere sosyal beceri çalışmalarına ilişkin Türkiye'de hakemli dergilerde yayınlanmış makaleler ve yayımlanmış yüksek lisans ve doktora tezleri incelenmiştir. Bu çalışma sonucunda 13 araştırmaya ulaşıımıştır. Çalışma kapsamına seçilen araştırmalarda aşağıdaki kriterler dikkate alınmıştır:

a) Araştırmaların zihin yetersizliği olan bireylere sosyal beceri öğretimi ile ilgili olması, 
b) Tek denekli uygulamalara yer vermesi

c) 2000-2017 yılları arasında Türkiye'de yapılmış tezler ve makaleler olmasıdır.

\section{Verilerin Toplanması}

Araştırma makalelerinin taranması sürecinde tarama için elektronik veri tabanları olarak Google Akademik arama motoru, Yükseköğretim Kurulu'nun (YÖK) Ulusal Tez Merkezi internet sitesi ve Abant İzzet Baysal Üniversitesi Kütüphanesi abone veri tabanları kullanılmıştır. İncelenecek araştırmalara ulaşabilmek için; 'sosyal beceri', 'sosyal beceri öğretimi', 'teşekkür etme', 'selam verme' gibi sosyal becerilerin adları anahtar kelimeler olarak alınmış, buna göre tarama yapılmıştır. Tarama sonucunda, çalışmada kullanılacak araştırmalar için a) 20002017 yıllarını kapsayan, b) Türkiye'de yayınlanmış olan, c) zihin yetersizliği olan bireylere sosyal beceri öğretimi gerçekleştirilen, d) tek denekli araştırma yöntemini kullanan araştırmalar seçilmiştir. Belirlenen ölçütlere göre araştırma için 13 çalışma belirlenmiş̧ir.

\section{Verilerin Analizi}

Araştırma alanında yer alan araştırmalar numaralandırılmıştır. Daha sonra araştırmacılar tarafından a) deneklerin özellikleri, b) bağımlı değişken, c) bağımsız değişken, d) araştırma deseni, e) ortam, f) izleme ve genelleme, g) güvenirlik, h) sosyal geçerlik ve 1) bulgular verileri olmak üzere dokuz kategori belirlenmiştir. Her kategori ile ilgili veriler, oluşturulan tabloya işlenerek kısa analiz oluşturulmuştur. Tabloda, her kategoriyle ilgili bilgilerin yer alacağı sekiz sütun yer almıştır. Araştırmacılar araştırmaları okuyarak, oluşan kategorilere göre ayrıntılı not almıştır. Tüm kategorilerde elde edilen veriler ayrıntılı şekilde yazılmıştır. Araştırmacıların yorumları bu çalışmanın tartışma bölümünde kaynaklarla desteklenerek tartışılmıştır.

\section{Kodlamacılar Arası Güvenirlik}

Betimsel analiz süreci ile ilgili güvenirlik çalışması, belirlenen araştırmaların hepsi seçilerek, yüksek lisans eğitimlerini zihinsel engellilerin eğitimi alanında yapmış ve aynı alanda doktora yapmakta olan araştırmanın ikinci ve üçüncü yazarları tarafından araştırma değerlendirme formu kullanılarak belirlenen ölçütler kapsamında detaylı bir şekilde değerlendirilmesi ile gerçekleştirilmiştir. Kodlamacılar Arası Güvenirlik (KAG) hesaplaması [görüş birliği / (görüş birliği + görüş ayrılığı) x 100] formülü kullanılarak gerçekleştirilmiş ve kodlamacılar arası güvenirlik \%100 olarak belirlenmiştir.

\section{Bulgular}

Kaynak taraması sonucunda 13 araştırma incelenmiştir. Bu çalışmada ele alınan araştırma verileri, incelenen kategorilere göre tablolaştırılmıştır. Bu kategorilerde elde edilen bulgular, tabloda yer verilen bulgularla birlikte ayrıntılı şekilde rapor edilmiştir. Zihin yetersizliği olan bireylere sosyal beceri öğretimine ilişkin araştırmaların kısa analizi Tablo 1'de gösterilmiştir. 
Tablo.1 Zihin yetersizliği Olan Bireylere Sosyal Beceri Öğretimi Alanında Gerçekleştirilen Tek Denekli Araştırmalar

\begin{tabular}{|c|c|c|c|c|c|c|c|c|c|}
\hline Kaynak & $\begin{array}{c}\text { Denekleri } \\
n\end{array}$ & Bağımlı Değişken & $\begin{array}{l}\text { Bağımsız } \\
\text { Değiş̧ken }\end{array}$ & $\begin{array}{l}\text { Araştırma } \\
\text { Deseni }\end{array}$ & Ortam & $\dot{\mathbf{I}} / \mathbf{G}$ & $\begin{array}{c}\text { GAG/U } \\
\mathbf{G}\end{array}$ & SG & Bulgular \\
\hline $\begin{array}{l}\text { Alptekin, } \\
\text { S. } \\
2010\end{array}$ & $\begin{array}{l}\text { Zihin } \\
\text { yetersizliği } \\
\text { E: } 1(11)\end{array}$ & $\begin{array}{l}\text { Teşekkür etme, } \\
\text { yardım etme, izin } \\
\text { isteme }\end{array}$ & $\begin{array}{l}\text { Akran } \\
\text { modellerle } \\
\text { doğrudan } \\
\text { ögretim }\end{array}$ & $\begin{array}{l}\text { Davranışlar arası } \\
\text { yoklama } \\
\text { denemeli çoklu } \\
\text { yoklama modeli }\end{array}$ & $\begin{array}{l}\text { Okul } \\
\text { kütüphanesi }\end{array}$ & $\mathrm{V} / \mathrm{V}$ & $\mathrm{Y} / \mathrm{V}$ & $\mathrm{V}$ & $\begin{array}{l}\text { Araştırmanın sonucunda, akran } \\
\text { modellerden yararlanarak doğrudan } \\
\text { öğretim yaklaşımı ile yapılan öğretim, } \\
\text { hedeflenen davranışlarını kazandırmada, } \\
\text { kazanılanların sürdürülmesinde ve } \\
\text { genellenmesinde etkilidir. }\end{array}$ \\
\hline $\begin{array}{l}\text { Avcioğlu, } \\
\text { H. } \\
2012-\mathrm{a}\end{array}$ & $\begin{array}{l}\text { Zihin } \\
\text { yetersizliği } \\
\text { E:2 (8), } \\
\text { K:1 (8) }\end{array}$ & Kendini tanitma & Drama & $\begin{array}{l}\text { Denekler arası } \\
\text { yoklama } \\
\text { denemeli çoklu } \\
\text { yoklama modeli }\end{array}$ & $\begin{array}{l}\text { RAM } \\
\text { bünyesinde } \\
\text { oyun odas1 }\end{array}$ & $\mathrm{V} / \mathrm{V}$ & $\mathrm{V} / \mathrm{V}$ & $\mathrm{Y}$ & $\begin{array}{l}\text { Araştırmanın sonucunda, zihinsel } \\
\text { yetersizliği olan çocukların kendini } \\
\text { tanıtma becerisini kazandıkları, } \\
\text { sürdürebildikleri ve devam ettikleri } \\
\text { okuldaki akranlarına serbest oyun } \\
\text { etkinliklerinde genelleyebildikleri } \\
\text { görülmüştür. }\end{array}$ \\
\hline $\begin{array}{l}\text { Avcioğlu, } \\
\text { H. } \\
2012-b\end{array}$ & $\begin{array}{l}\text { Zihin } \\
\text { yetersizliği } \\
\text { E:5 (10- } \\
12) \\
\text { K:4 (10- } \\
12)\end{array}$ & $\begin{array}{l}\text { Kendini kontrol } \\
\text { etme }\end{array}$ & $\begin{array}{l}\text { Kendini } \\
\text { yönetme } \\
\text { stratejisi }\end{array}$ & $\begin{array}{l}\text { Denekler arası } \\
\text { yoklama } \\
\text { denemeli çoklu } \\
\text { yoklama modeli }\end{array}$ & $\begin{array}{l}\text { Eğitim } \\
\text { kurumu izin } \\
\text { verilen oyun } \\
\text { odası }\end{array}$ & $\mathrm{V} / \mathrm{V}$ & $\mathrm{V} / \mathrm{V}$ & $\mathrm{Y}$ & $\begin{array}{l}\text { Araştırma bulguları; kendini yönetme } \\
\text { stratejileri ile sunulan öğretim paketinin } \\
\text { zihinsel yetersizliği olan öğrencilerin } \\
\text { başkalarına zarar vermeden öfkesini ortaya } \\
\text { koyma, başkalarıyla olan farklılıkları } \\
\text { konuşarak çözme ve başkalarıyla olan } \\
\text { problemlerini kavga etmeden çözme } \\
\text { becerilerini kazanmalarında etkili } \\
\text { olduğunu ve bu becerileri uygulama sona } \\
\text { erdikten sonra da kullanmaya devam } \\
\text { ettiklerini göstermiştir. }\end{array}$ \\
\hline
\end{tabular}




\begin{tabular}{|c|c|c|c|c|c|c|c|c|c|}
\hline Kaynak & 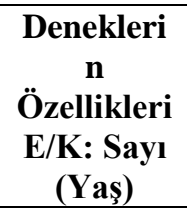 & Bağımlı Değişken & $\begin{array}{l}\text { Bağımsız } \\
\text { Değișken }\end{array}$ & $\begin{array}{l}\text { Araştırma } \\
\text { Deseni }\end{array}$ & Ortam & $\dot{\mathbf{I}} / \mathbf{G}$ & $\begin{array}{c}\mathbf{G A G} / \mathbf{U} \\
\mathbf{G}\end{array}$ & SG & Bulgular \\
\hline $\begin{array}{l}\text { Avcioğlu, } \\
\text { H. } \\
2013\end{array}$ & $\begin{array}{l}\text { Zihin } \\
\text { yetersizliği } \\
\text { E: } 2(11- \\
12), \\
\text { K:1 (12) }\end{array}$ & Selam verme & $\begin{array}{l}\text { Videoyla } \\
\text { model olma }\end{array}$ & $\begin{array}{l}\text { Denekler arası } \\
\text { yoklama } \\
\text { denemeli çoklu } \\
\text { yoklama modeli }\end{array}$ & $\begin{array}{l}\text { Eğitim } \\
\text { kurumu izin } \\
\text { verilen } \\
\text { bireysel } \\
\text { eğitim sınıfı }\end{array}$ & $\mathrm{V} / \mathrm{V}$ & $\mathrm{V} / \mathrm{V}$ & $\mathrm{V}$ & $\begin{array}{l}\text { Araştırma bulguları; videoyla model } \\
\text { olmayla öğretim sonucunda zihinsel } \\
\text { yetersizliği olan öğrencilerin selam verme } \\
\text { becerisini kazandıklarını, sürdürdüklerini } \\
\text { ve farklı ortam ve kişilere genellediklerini } \\
\text { göstermiştir. }\end{array}$ \\
\hline $\begin{array}{l}\text { Çadır, D. } \\
2008\end{array}$ & $\begin{array}{l}\text { Zihin } \\
\text { yetersizliği } \\
\text { E:7 (10- } \\
11) \\
\text { K:2 (11) }\end{array}$ & $\begin{array}{l}\text { Başkalarını oyun } \\
\text { oynamaya davet } \\
\text { etme, } \\
\text { başkalarından } \\
\text { aldığı eşyayı geri } \\
\text { getirme, üstlendiği } \\
\text { görev ya da } \\
\text { görevleri yerine } \\
\text { getirme }\end{array}$ & Müzik terapi & $\begin{array}{l}\text { Denekler arası } \\
\text { yoklama } \\
\text { denemeli çoklu } \\
\text { yoklama modeli }\end{array}$ & $\begin{array}{l}\text { Eğitim } \\
\text { kurumu izin } \\
\text { verilen } \\
\text { derslik }\end{array}$ & $\mathrm{Y} / \mathrm{V}$ & $\mathrm{V} / \mathrm{V}$ & $\mathrm{V}$ & $\begin{array}{l}\text { Bu çalışmanın sonunda, araştırmaya } \\
\text { katılan zihinsel engelli öğrencilerin müzik } \\
\text { terapi yöntemine dayalı olarak hazırlanan } \\
\text { ve müzik etkinlikleriyle desteklenen sosyal } \\
\text { beceri öğretim programından } \\
\text { yararlandıkları, öğretilmeye çalışılan hedef } \\
\text { becerileri öğrendikleri ve müzik terapi } \\
\text { öğretim yönteminin etkili olduğu } \\
\text { izlenimini vermektedir. }\end{array}$ \\
\hline $\begin{array}{l}\text { Çadır, D. } \\
\text { Avcıŏlu, } \\
\text { H. } \\
2013\end{array}$ & $\begin{array}{l}\text { Zihin } \\
\text { yetersizliği } \\
\text { E:5 (10- } \\
11) \\
\text { K:4 (10- } \\
11)\end{array}$ & $\begin{array}{l}\text { Başkalarını oyun } \\
\text { oynamaya davet } \\
\text { etme, } \\
\text { başkalarından } \\
\text { aldığı eşyayı geri } \\
\text { getirme, üstlendiği } \\
\text { görevleri yerine } \\
\text { getirme }\end{array}$ & Müzik terapi & $\begin{array}{l}\text { Denekler arası } \\
\text { yoklama } \\
\text { denemeli çoklu } \\
\text { yoklama modeli }\end{array}$ & $\begin{array}{l}\text { Eğitim } \\
\text { kurumu izin } \\
\text { verilen sınıf }\end{array}$ & $\mathrm{V} / \mathrm{V}$ & $\mathrm{V} / \mathrm{V}$ & $\mathrm{V}$ & $\begin{array}{l}\text { Araştırma bulguları; müzik terapi yöntemi } \\
\text { ile sunulan öğretim paketinin zihinsel } \\
\text { yetersizliği olan öğrencilerin, hedef } \\
\text { becerileri kazanmalarında etkili olduğunu } \\
\text { ve bu becerileri kazanan öğrencilerin } \\
\text { uygulama sona erdikten sonra da bu } \\
\text { becerileri kullanmaya devam ettiklerini } \\
\text { göstermiştir. }\end{array}$ \\
\hline
\end{tabular}




\begin{tabular}{|c|c|c|c|c|c|c|c|c|c|}
\hline Kaynak & $\begin{array}{l}\text { Denekleri } \\
\quad n \\
\text { Özellikleri } \\
\text { E/K: Sayı } \\
\text { (Yaş) }\end{array}$ & Bağımlı Değișken & $\begin{array}{l}\text { Bağımsız } \\
\text { Değişken }\end{array}$ & $\begin{array}{l}\text { Araştırma } \\
\text { Deseni }\end{array}$ & Ortam & $\dot{\mathbf{I}} / \mathbf{G}$ & $\begin{array}{c}\text { GAG/U } \\
\mathbf{G}\end{array}$ & SG & Bulgular \\
\hline $\begin{array}{l}\text { Çakır, S. } \\
2006\end{array}$ & $\begin{array}{l}\text { Zihin } \\
\text { yetersizliği } \\
3(17-18)\end{array}$ & $\begin{array}{l}\text { Telefonla uygun } \\
\text { şekilde konuşma }\end{array}$ & $\begin{array}{l}\text { Doğrudan } \\
\text { öğretim }\end{array}$ & $\begin{array}{l}\text { Denekler arası } \\
\text { çoklu yoklama } \\
\text { modeli }\end{array}$ & - & $\mathrm{V} / \mathrm{V}$ & $\mathrm{V} / \mathrm{V}$ & $\mathrm{V}$ & $\begin{array}{l}\text { Araştırmada elde edilen bulgulara göre, } \\
\text { doğrudan öğretim yaklaşımıyla hazırlanan } \\
\text { telefonla konuşma sosyal beceri öğretimi, } \\
\text { araştırma kapsamındaki üç öğrencinin de } \\
\text { beceriyi kazanmalarında ve } \\
\text { sürdürmelerinde etkili olmuştur. }\end{array}$ \\
\hline $\begin{array}{l}\text { Çelik, H. } \\
2010\end{array}$ & $\begin{array}{l}\text { Zihin } \\
\text { yetersizliği } \\
\text { E: } 2(12), \\
\text { K:4 (10- } \\
12)\end{array}$ & $\begin{array}{l}\text { Kendini kontrol } \\
\text { etme, saldırgan } \\
\text { davranışlarla başa } \\
\text { çıkma }\end{array}$ & $\begin{array}{l}\text { Kendi } \\
\text { kendini } \\
\text { yönetme }\end{array}$ & $\begin{array}{l}\text { Denekler arası } \\
\text { yoklama } \\
\text { denemeli çoklu } \\
\text { yoklama modeli }\end{array}$ & $\begin{array}{l}\text { Eğitim } \\
\text { kurumu izin } \\
\text { verilen } \\
\text { derslik }\end{array}$ & $\mathrm{V} / \mathrm{V}$ & $\mathrm{V} / \mathrm{V}$ & $\mathrm{V}$ & $\begin{array}{l}\text { Araştırmada elde edilen bulgulara göre de } \\
\text { kendi kendini yönetme tekniğine dayalı } \\
\text { olarak hazırlanan sosyal beceri öğretim } \\
\text { programının, araştırmaya katılan altı } \\
\text { zihinsel yetersizliği olan öğrencinin hedef } \\
\text { sosyal becerileri kazanmalarında ve } \\
\text { genellemelerinde etkili olduğu } \\
\text { saptanmıştır. }\end{array}$ \\
\hline $\begin{array}{l}\text { Çifci, İ. } \\
2001\end{array}$ & $\begin{array}{l}\text { Zihin } \\
\text { yetersizliği } \\
\text { E: } 5(15- \\
16) \\
\text { K: } 4(16- \\
\text { 19) }\end{array}$ & $\begin{array}{l}\text { Özür dileme, alay } \\
\text { edilmeyle başa } \\
\text { çıkma, uygun } \\
\text { olmayan } \\
\text { dokunmaktan } \\
\text { kaçınma }\end{array}$ & $\begin{array}{l}\text { Bilişsel } \\
\text { süreç } \\
\text { yaklaşımına } \\
\text { dayalı olarak } \\
\text { hazırlanan } \\
\text { sosyal beceri } \\
\text { öğretim } \\
\text { programı }\end{array}$ & $\begin{array}{l}\text { Denekler arası } \\
\text { yoklama evreli } \\
\text { çoklu yoklama } \\
\text { modeli }\end{array}$ & $\begin{array}{l}\text { Mesleki } \\
\text { eğitim } \\
\text { merkezi izin } \\
\text { verilen } \\
\text { derslik }\end{array}$ & $\mathrm{Y} / \mathrm{V}$ & $\mathrm{V} / \mathrm{V}$ & $\mathrm{Y}$ & $\begin{array}{l}\text { Araştırma sonucunda bilişsel süreç } \\
\text { yaklaşımına dayalı olarak hazırlanan } \\
\text { sosyal beceri öğretim programının toplam } \\
\text { dokuz zihinsel engelli öğrencinin hedef } \\
\text { sosyal becerileri kazanmalarında ve bu } \\
\text { becerileri genelleyebilmelerinde etkili } \\
\text { olduğu görülmüştür. }\end{array}$ \\
\hline
\end{tabular}




\begin{tabular}{|c|c|c|c|c|c|c|c|c|c|}
\hline Kaynak & $\begin{array}{c}\text { Denekleri } \\
\quad n \\
\text { Özellikleri } \\
\text { E/K: Sayı } \\
\quad \text { (Yaş) }\end{array}$ & Bağımlı Değișken & $\begin{array}{l}\text { Bağımsız } \\
\text { Değișken }\end{array}$ & $\begin{array}{l}\text { Arasstırma } \\
\text { Deseni }\end{array}$ & Ortam & $\dot{\mathbf{I}} / \mathbf{G}$ & $\begin{array}{c}\text { GAG/U } \\
\mathbf{G}\end{array}$ & SG & Bulgular \\
\hline $\begin{array}{l}\text { Dağseven } \\
\text { Emecen, } \\
\text { D. } \\
2011\end{array}$ & $\begin{array}{l}\text { Epilepsi, } \\
\text { Zihin } \\
\text { yetersizliği } \\
\text { E:1 (13), } \\
\text { K:1 (11) }\end{array}$ & $\begin{array}{l}\text { Teşekkür etme, } \\
\text { paylaşma }\end{array}$ & $\begin{array}{l}\text { Doğrudan } \\
\text { öğretim, } \\
\text { Bilişsel } \\
\text { süreç } \\
\text { yaklaşımı }\end{array}$ & $\begin{array}{l}\text { Uyarlamalı } \\
\text { dönüşümlü } \\
\text { uygulamalar } \\
\text { modeli }\end{array}$ & $\begin{array}{l}\text { Eğitim } \\
\text { kurumu } \\
\text { bireysel } \\
\text { çalışma sınıfı }\end{array}$ & $\mathrm{V} / \mathrm{V}$ & $\mathrm{V} / \mathrm{V}$ & $\mathrm{V}$ & $\begin{array}{l}\text { Araştırmada elde edilen bulgulara göre, } \\
\text { doğrudan öğretim yaklaşımının bir no'lu } \\
\text { deneğe sosyal becerilerin } \\
\text { kazandırılmasında daha etkili olduğu, iki } \\
\text { no'lu denekte ise benzer etkililikte olduğu } \\
\text { izlenimi edinilmektedir. Sosyal becerilerin } \\
\text { kazandırılmasında, toplam öğretim süresi } \\
\text { ve yanlış tepki sayısı açısından doğrudan } \\
\text { öğretim yaklaşımının daha verimli olduğu } \\
\text { sonucuna ulaşılmıştır. }\end{array}$ \\
\hline $\begin{array}{l}\text { Özokçu, } \\
\text { O. } \\
2008\end{array}$ & $\begin{array}{l}\text { Zihin } \\
\text { yetersizliği } \\
\text { E: } 1(12) \\
\text { K: } 2(11- \\
12)\end{array}$ & $\begin{array}{l}\text { Özür dileme, } \\
\text { yardım isteme, } \\
\text { başladığı bir işi } \\
\text { zamanında bitirme }\end{array}$ & $\begin{array}{l}\text { Doğrudan } \\
\text { öğretim }\end{array}$ & $\begin{array}{l}\text { Denekler arası } \\
\text { yoklama evreli } \\
\text { çoklu yoklama } \\
\text { modeli }\end{array}$ & $\begin{array}{l}\text { Eğitim } \\
\text { kurumu } \\
\text { kaynak oda }\end{array}$ & $\mathrm{Y} / \mathrm{V}$ & $\mathrm{V} / \mathrm{V}$ & $\mathrm{V}$ & $\begin{array}{l}\text { Araştırmanın sonucunda doğrudan öğretim } \\
\text { yaklaşımına dayalı olarak hazırlanan } \\
\text { sosyal beceri öğretim programının toplam } \\
\text { üç zihinsel engelli öğrencinin hedef sosyal } \\
\text { becerileri kazanmalarında ve bu becerileri } \\
\text { genelleyebilmelerinde etkili olduğu } \\
\text { görülmüştür. }\end{array}$ \\
\hline $\begin{array}{l}\text { Sazak, E. } \\
2003\end{array}$ & $\begin{array}{l}\text { Zihin } \\
\text { yetersizliği } \\
\text { K: } 1(9)\end{array}$ & $\begin{array}{l}\text { Kendini tanıtma, } \\
\text { yardım ya da bilgi } \\
\text { isteme, paylaşma }\end{array}$ & $\begin{array}{l}\text { Akran aracılı } \\
\text { sosyal beceri } \\
\text { öğretim } \\
\text { programı }\end{array}$ & $\begin{array}{l}\text { Davranışlar arası } \\
\text { yoklama } \\
\text { denemeli çoklu } \\
\text { yoklama modeli }\end{array}$ & $\begin{array}{l}\text { Rehberlik } \\
\text { Araştırma } \\
\text { Merkezi test } \\
\text { odası }\end{array}$ & $\mathrm{V} / \mathrm{Y}$ & $\mathrm{V} / \mathrm{V}$ & $\mathrm{Y}$ & $\begin{array}{l}\text { Araştırmanın sonunda, akran aracılı sosyal } \\
\text { beceri öğretim programının, öğrenciye } \\
\text { ögretilmesi hedeflenen kendini tanıtma, } \\
\text { yardım ya da bilgi isteme ve paylaşma } \\
\text { becerilerinin kazandırılmasında etkili } \\
\text { olduğu görülmüştür. }\end{array}$ \\
\hline
\end{tabular}




\begin{tabular}{|c|c|c|c|c|c|c|c|c|c|}
\hline Kaynak & $\begin{array}{c}\text { Denekleri } \\
n \\
\text { Özellikleri } \\
\text { E/K: Sayı } \\
\text { (Yaş) }\end{array}$ & Bağımlı Değişken & $\begin{array}{l}\text { Bağımsız } \\
\text { Değişken }\end{array}$ & $\begin{array}{c}\text { Araştırma } \\
\text { Deseni }\end{array}$ & Ortam & $\dot{\mathbf{I}} / \mathbf{G}$ & $\begin{array}{c}\text { GAG/U } \\
\mathbf{G}\end{array}$ & SG & Bulgular \\
\hline $\begin{array}{l}\text { Türer, H. } \\
2010\end{array}$ & $\begin{array}{l}\text { Zihin } \\
\text { yetersizliği } \\
\text { E: } 2(7), \\
K: 1(8)\end{array}$ & $\begin{array}{l}\text { Teşekkür etme, } \\
\text { özür dileme }\end{array}$ & $\begin{array}{l}\text { Doğrudan } \\
\text { öğretim }\end{array}$ & $\begin{array}{l}\text { Denekler arası } \\
\text { yoklama } \\
\text { denemeli çoklu } \\
\text { yoklama modeli }\end{array}$ & $\begin{array}{l}\text { Eğitim } \\
\text { kurumu } \\
\text { bireysel } \\
\text { eğitim sınıfı }\end{array}$ & $\mathrm{V} / \mathrm{V}$ & $\mathrm{Y} / \mathrm{Y}$ & $\mathrm{Y}$ & $\begin{array}{l}\text { Araştırmadan elde edilen bulgulara göre } \\
\text { doğrudan öğretim yönteminin, } 3 \\
\text { öğrencinin de teşekkür etme ve özür } \\
\text { dileme becerilerin kazanmalarında, farklı } \\
\text { ortam, kişi ve nesnelere genellemelerinde } \\
\text { ve öğretimden } 7,21 \text { ve } 35 \text { gün sonra } \\
\text { sürdürmelerinde etkili olduğu } \\
\text { gözlenmiştir. }\end{array}$ \\
\hline
\end{tabular}

E: Erkek, K: Kı, İ: İzleme, G: Genelleme, GAG: Gözlemciler Arası Güvenirlik, UG: Uygulama Güvenirliği, SG: Sosyal Geçerlik, V: Var, Y: Yok 


\section{Bağımlı ve bağımsız değiş̧kenler}

Araştırmalarda bağımlı değişken olarak; alay edilmeyle başa çıkma, uygun olmayan dokunmaktan kaçınma, teşekkür etme, paylaşma, başkalarını oyun oynamaya davet etme, başkalarından aldığı eşyayı geri getirme, üstlendiği görevleri yerine getirme, kendini tanıtma, kendini kontrol etme, selam verme, yardım ya da bilgi isteme, devam eden etkinliğe katılma, saldırgan davranışlarla başa çıkma, özür dileme, yardım etme, izin isteme becerilerinin seçildiği görülmüştür., Bağımsız değişken olarak da bilişsel süreç yaklaşımı, doğrudan öğretim, müzik terapi, drama, kendini yönetme stratejisi, videoyla model olma, akran aracilı sosyal beceri öğretim programı, sosyal öyküler ve akran modellerle doğrudan öğretim yöntem ve stratejileri kullanılarak bağımsız değişkenlerin bağımlı değişkenler üzerindeki etkileri incelenmiştir.

\section{Denekler}

İncelenen araştırmalarda yer alan denekler, a) yaş, ve b) cinsiyet değişkenleri göz önünde bulundurularak incelenmiş ve deneklere ilişkin demografik bilgilere Tablo 2'de yer verilmiştir.

Tablo.2 Deneklerin Demografik Bilgileri

\begin{tabular}{clc}
\hline & \multicolumn{1}{c}{ Değişkenler } & Frekans \\
\hline \multirow{2}{*}{ Yaş } & 7-11 (Son, ikinci çocukluk) & 40 \\
& $12-19$ (Ergenlik) & 21 \\
\multirow{2}{*}{ Cinsiyet } & K1z & 25 \\
& Erkek & 33 \\
\hline
\end{tabular}

Araştırmalarda toplam 61 deneğin yer aldığı, deneklerin 40’ının 7-11 yaş (son, ikinci çocukluk) aralığında ve 21'inin 12-19 (ergenlik) yaş aralığında olduğu belirlenmiştir. Deneklerin 25'i kız, 33'ü ise erkektir. Cinsiyeti belirtilmeyen 3 denek bulunmaktadır. Bunun yanı sıra araştırmalarda 8 normal gelişim gösteren birey de öğretimde araştırmacılara yardım etmiştir.

\section{Araştırma desenleri}

$\mathrm{Bu}$ çalışmada incelenen araştırmaların belirlenmesi aşamasında yer alan ölçütlerden biri tek denekli deneysel desenlerin kullanılmış olmasıdır. Bu doğrultuda Tablo 3'de araştırmalarda kullanılan tek denekli deneysel desenlere yer verilmiştir.

Tablo.3 Araştırmalarda Kullanılan Tek Denekli Deneysel Desenler

\begin{tabular}{lc}
\hline \multicolumn{1}{c}{ Değişkenler } & Frekans \\
\hline Denekler arası yoklama denemeli çoklu yoklama modeli & 7 \\
Denekler arası yoklama evreli çoklu yoklama modeli & 2 \\
Davranışlar arası yoklama denemeli çoklu yoklama modeli & 2 \\
Uyarlamalı dönüşümlü uygulamalar modeli & 1 \\
\hline
\end{tabular}

Yukarıdaki Tablo 3 incelendiğinde seçilen araştırmalarda en çok kullanılan tek denekli deneysel desenin yoklama denemeli çoklu yoklama modeli (9) olduğu, bu modelin de en fazla denekler arasında desenlendiği (7) görülmektedir. İkinci en çok kullanılan modelin de yoklama evreli çoklu yoklama modeli (2) olduğu, yine bu modelde de en fazla denekler arasında desenlendiği (2) sonucuna ulaşılmıştır. Bir araştırmada da uyarlamalı dönüşümlü uygulamalar modelinin kullanıldığı tespit edilmiş.

\section{İzleme ve Genelleme Süreci}

Ulaşılan araştırmaların büyük çoğunluğunda (10) izleme sürecinin planlandığı ve bu sürece ilişkin verilerin toplandığ1 görülmüştür. Araştırmalarda genellikle izleme düzeyi veri toplama formuna yer verilmiştir. İzleme verilerinin genellikle öğretim bittikten 1,3 ve 4 hafta sonra toplandığ 1 görülmüş, en uzun izleme verisinin de öğretim bittikten 35 gün sonra toplandığı bilgisi elde edilmiştir. Genelleme açısından incelediğimizde de yine incelenen araştırmaların çoğunda (12) ortam, araç-gereç ve kişilerarası genelleme verilerinin toplandığ görülmüştür. 


\section{Gözlemciler Arası Güvenirlik, Uygulama Güvenirliği ve Sosyal Geçerlik}

Zihin yetersizliği olan bireylere sosyal beceri çalışmalarıyla ilgili araştırmaların birinde sadece gözlemciler arası güvenirlik, bir diğerinde ise hem gözlemciler arası güvenirlik hem de uygulama güvenirliği verisi toplanmadığ 1 tespit edilmiştir.

Zihin yetersizliği olan bireylere sosyal beceri çalışmalarıyla ilgili araştırmaların 8'inde sosyal geçerlik verileri toplanmıştır. Sosyal geçerlik verileri genel olarak öznel değerlendirme yoluyla öğretmenlerden elde edilmiştir. Öğretmenler öncelikle öğretilmesi hedeflenen sosyal becerileri belirlerken becerilerin öğrenciler için gerekli olup olmadığını değerlendirerek görüş bildirmişlerdir. Öğretilmesi hedeflenen beceriler, öğrencileri tanıyan sınıf öğretmenleri tarafından görüş alınarak belirlenmiştir. Sosyal geçerlik verisi toplanan araştırmaların ikisinde (Çadır, 2008; Dağseven-Emecen, 2011) araştırmacılar tarafından hazırlanan "Sosyal Geçerlik Formu” ile sosyal geçerlik verisi toplamıştır. Bu araştırmalardan birinde (Dağseven-Emecen, 2011), amaç bölümünün ve on sorudan oluşan, soruların Evet düşünüyorum ( ), Hayır düşünmüyorum ( ) ve Kararsızım ( ) şeklinde işaretleneceği, bölümler yer almaktadır. Diğer bir araştırmada ise (Çadır, 2008), araştırma kapsamında öğretilmesi hedeflenen beceriler, öğrencileri en iyi tanıyan öğretmenler tarafından belirlenmiş ve araştırmacı tarafından Sosyal Geçerlik Formu hazırlanmıştır. Avcıoğlu (2012-b) ve Avcıoğlu (2013), araştırmalarında ise araştırma sona erdikten sonra araştırmanın başlama düzeyindeki ve en son öğretim oturumundaki görüntüleri annelere ve öğretmenlere ayrı ayrı izletilmiş, daha sonra elde edilen bulguların uygunluğunu değerlendirmek üzere öğrencilerin annelerinden ve öğretmenlerinden görüşler alarak sosyal geçerlik verisi toplamıştır.

\section{Tartışma ve Sonuç}

$\mathrm{Bu}$ çalışmada zihin yetersizliği olan bireylere sosyal beceri öğretimiyle ilgili 13 araştırma incelenmiş ve belirlenen ölçütlere göre analiz edilmiştir. Bu bölümde her bir kategoride öne çıkan bulgular tartışılmıştır.

Zihin yetersizliği olan öğrencilere sosyal beceri öğretimini ele alan araştırmalar daha çok 7-11 yaş aralığındaki son çocukluk grubundaki bireylerle gerçekleştirilmiştir. Son çocukluk grubundan sonra ergenlik çağlarındaki bireylerin de araştırmalarda (Avcıoğlu, 2012-b; Avcığlu, 2013; Çakır, 2006; Çelik,2010; Çifci, 2001; DağsevenEmecen, 2011; Özokçu, 2008) yer aldığı görülmektedir. Sosyal beceriler, özbakım becerileri gibi erken yaşlardan başlayarak öğretilmesi gerekli becerilerdir. Hem küçük yaşlarda hem de ileri yaşlarda kazandırılması gerektiği düşünülmektedir Bu becerilerin, yetersizliği olmayan çocuklarda rastlantısal yollarla, daha çok gözlem ve taklit yoluyla kazanıldığı bilinmektedir. Zihinsel yetersizliği olan bireylerin ise taklit becerilerinin sınırlı olması bu becerilerin öğretilmesi gerekliliğini ortaya çıkarmaktadır. Sosyal becerilerin küçük yaşlarda edinimi önemli olmakla birlikte yaşa bağlı olarak öğrenilmesi gereken sosyal beceriler farklılık göstermektedir (Çolak, 2007). Bu çalışmada daha çok son çocukluk ve ergenlik dönemi zihin yetersizliği olan çocuklara sosyal becerilerin kazandırıldığı görülmektedir. Çalışma kapsamında değerlendirilen araştırmalar incelendiğinde erken çocukluk ve genç yetişkinlik dönemindeki bireylerle çalışılmadı̆̆

Sosyal beceriler birçok araştırmacı tarafından farklı şekillerde sınıflandırılmıştır. Her ne kadar farklı sınıflandırılmış olsa da, incelenen araştırmalarda, teşekkür etme, paylaşma, özür dileme, yardım etme, yardım isteme, izin isteme, başladığı işi zamanında bitirme becerileri, telefonla uygun şekilde konuşma, başkalarını oyun oynamaya davet etme, başkalarından aldığı eşyayı geri getirme, üstlendiği görevi yerine getirme, kendini kontrol etme, saldırgan davranışlarla başa çıkma, kendini tanıtma gibi daha çok etkileşim kurma becerilerinin ve kişiler arası becerilerin kazandırıldığı görülmektedir. Yetersizliği olan bireylere sosyal beceri öğretiminde, seçilen sosyal becerinin çocuk için gerekli olması ve çocuğun yetersizliği göz önünde bulundurularak seçilmesi gerekmektedir (Avcıoğlu, 2007). Bu araştırmalarda, seçilmiş olan sosyal becerilerin çocukların okulda ve okul dışındaki sosyal çevrelerinde kullanabilecekleri beceriler olması nedeniyle yapılan araştırmaların zihin yetersizliği olan bireyler için önemli olduğu düşünülmektedir. Türkiye'de yapılan üç araştırmada, saldırgan davranışlarla ve alay edilmeyle başa çıkma becerisi çalışılması dikkat çekmektedir. Şiddetin ve okullarda zorbalığın görülme sıklığının son yıllarda artış gösterdiği ve birçok öğrencinin de bu olaylarla bir şekilde karşı karşıya kaldığı bilinmektedir. Zihin yetersizliği olan bireylerin de her birey gibi şiddet ve zorbalığa maruz kalma olasılığının var olduğu düşünülürse, bu tür becerilerin kazandırılmasının son derece önemli olduğu ve bu tür araştırılmaların sayısının arttırılması gerektiği düşünülmektedir.

$\mathrm{Bu}$ çalışmada incelenen araştırmalarda sosyal becerilerin öğretiminde doğrudan öğretim yaklaşımı, kendini yönetme stratejisi, akran öğretimi, müzik terapi yöntemi, bilişsel süreç yaklaşımı, videoyla model olma, ve drama yöntemi kullanılmıştır. İncelenen araştırmaların sadece biri (Dağseven-Emecen, 2011) yöntemlerin 
karşılaştırmasına yer vermiştir. Burada sözü edilen yöntem ve tekniklerin hedef becerilerin öğretiminde etkili olduğu görülmüştür. Ancak son zamanlarda yapılan araştırmalarda daha çok bilimsel dayanaklı uygulamalara yer verildiği görülmektedir. Zihin yetersizliği olan bireylere yönelik bilimsel dayanaklı uygulamaların yaygınlaştırılması ve sayının arttırılması, uygulanan program ve öğretimin yetersizliği olan çocukların gelişimine olumlu etkisini daha iyi görmemizi sağlayacaktır.

$\mathrm{Bu}$ çalışma kapsamında incelenen araştırmalara bakıldığında tek denekli deneysel desenlerden yoklama denemeli çoklu yoklama modellerinin yoğun olarak kullanıldığı görülmektedir. Bellini ve Akullian'ın (2007) yaptığı meta analiz çalışmasında otizmli çocuklar ve ergenlerin video modelle sosyal beceri öğretim uygulamalarının yapıldığı 23 tek denekli araştırma örtüşmeyen veri yüzdesi hesaplanarak incelenmiştir. İncelenen araştırmalar 1987 ile 2005 yılları arasına gerçekleştirilmiştir. Bu araştırmalara yaşları 3 ile 20 arasında olan toplam 73 denek katılmıştır. İncelenen 23 araştırmanın 22'si çoklu başlama ya da çoklu yoklama modelleri kullanılarak gerçekleştirilmiştir. 1 araştırmada ise ABA modeli kullanılmıştır. Çoklu başlama ya da çoklu yoklama modelleri kullanılan 22 araştırmanın 16'sında sadece çoklu başlama, 3'ünde çoklu başlama ve değişen ölçütler, 2'sinde de çoklu başlama ve dönüşümlü uygulamalar, 1'inde de çoklu başlama ve ABA modelleri kullanılmıştır.

İncelenen araştırmalarda izleme sürecinin planlandığ Araştırmaların bulgularına bakıldığında sosyal beceriler için ayrı ayrı izleme düzeyi veri toplama formu hazırlanmıştır. Veri toplama formu her araştırmanın amacına uygun olarak araştırmacı tarafından oluşturulmuştur. Çalışmaların tümünde katılımcıların edindikleri becerileri öğretimden sonra koruduğu ve bu becerileri farklı ortam, kişi ve araç-gereçlere genelledikleri görülmüştür. Bu bulgu ülkemizde genelleme ve kalıcılık çalışmalarına verilen önemin giderek arttığını göstermektedir. Öğrenilen beceri ya da davranışın öğretim dışındaki ortamlara, kişilere, uyaranlara genellenebilmesi bireyin doğal olaylarda pekiştirilmesini ve çevresiyle olumlu yönde etkileşim kurmasını sağlamaktadır (Tekin-İftar ve Kırcaali-İftar, 2001).

Araştırmalar incelendiğinde 13 araştırmadan 5'inde sosyal geçerlik verilerinin toplanmadığı görülmektedir. Sosyal geçerlik verisine yer verilmeyen bir çalışmada, sosyal geçerlik verisi toplanmadığının belirtilmesinin yanı sıra, ileri araştırmalarda, araştırmaya katılan çocukların kendileri, anne-babaları ve öğretmenlerinden sosyal geçerlik verilerinin toplanmasının öneri olarak sunulduğu görülmektedir. İncelenen araştırmaların sosyal geçerliği, öncelikle öğretilmesi hedeflenen sosyal becerilerin öğrenciler için gerekli olup olmadığına bakılarak belirlenmiştir. Bir uygulamayla ilgili değerlendirme yaparken uygulamanın sadece etkili olup olmadığını dikkate almak yeterli görülmemektedir. Kullanılan yöntemin pratik bir şekilde uygulanıp uygulanmadığı, yöntemin uygulanmaya değer olup olmadığı, uygulama yapılan bireylerin kazandırılan davranış değişikliğini yeterli bulup bulmadığı, elde edilen çıktıların uygulama yapılan bireylerin yaşam kaliteleri üzerinde anlamlı bir değişikliğe neden olup olmadığı gibi sosyal açıdan önemli olan boyutlarının da sorgulanması gerekmektedir. Bu bağlamda zihin yetersizliği olan bireylere yeni sosyal beceriler kazandırmak ve bu sosyal becerileri toplum içinde kullanmalarını sağlamak için gerçekleştirilen öğretim uygulamalarında sosyal geçerlik verilerinin toplanmış olması oldukça önemli görülmektedir. Ülkemizde son yıllarda gerçekleştirilen araştırmalarda ağırlıklı olarak sosyal geçerlik verisinin toplandığı görülmektedir (Avcıŏ̆lu, 2012-a; Avcıŏ̆lu, 2013; Çadır, 2008; Çelik, 2010; Emecen, 2008). Bu durum sosyal geçerliğe verilen önemin giderek artmakta olduğunun bir göstergesidir.

Araştırmalar güvenirlik verileri açısından incelendiğinde araştırmaların büyük çoğunluğunda uygulama güvenirliği verisinin ve gözlemciler arası güvenirlik verisinin toplandığı görülmektedir. Bu da yapılan araştırmaların hepsinin planlandığı gibi uygulanmasına özen gösterildiğini karşımıza çıkarmaktadır. Ayrıca güvenirlik verilerinin toplanmış olması araştırmaların uygulama aşamalarıyla ilgili soru işaretlerini de ortadan kaldırmaktadır.

Bu çalışmada zihin yetersizliği olan bireylere sosyal beceri öğretimi çalışmalarına ilişkin Türkiye'de hakemli dergilerde yayınlanmış makaleler ve yayımlanmış yüksek lisans ve doktora tezlerinin incelenmesi amaçlanmıştır. Bu amaçla çalışmaya, 2000-2017 yılları arasında, zihinsel yetersizliği olan bireylere sosyal beceri öğretiminin tek denekli deneysel desenler kullanılarak yapılan araştırmalar dahil edilmiştir. Çalışmada, zihin yetersizliği olan bireylere sosyal beceri öğretimine ilişkin bilgi verilmiş ve zihin yetersizliği olan bireylere sosyal beceri öğretimiyle ilgili araştırmalar incelenmeye çalışılmıştır. Çalışma, 2000-2017 yılları arasında, zihin yetersizliği olan bireylere yönelik tek denekli araştırma olarak desenlenen, sosyal beceri öğretimine ilişkin, Türkiye'de hakemli dergilerde yayınlanmış makaleler ve yayımlanmış yüksek lisans ve doktora tezlerini içeren 13 araştırmanın gözden geçirilerek incelenmesiyle sınırlı olmasına rağmen, çalışmanın alanyazına ve araştırmacılara katkıda bulunacağı ve 1 şık tutacağı düşünülmektedir. Zihin yetersizliği olan bireylerin önemli sınırlılıklarından birinin de sosyal 
beceriler olduğu düşünülürse bu alanda gerçekleştirilen çalışmaların az sayıda olduğu ve zihin yetersizliği olan bireylerin daha kaliteli bir yaşam sürmeleri adına araştırmacıların bu alana önem vermesi gerektiği söylenebilir.

$\mathrm{Bu}$ çalışmadan yola çıkarak ileride, (a) zihin yetersizliği olan bireylere tek denekli deneysel desenler dışında, farklı deneysel yöntemlerin kullanıldığı araştırmaların, (b) farklı yetersizlik guruplarındaki bireylerin yer aldığ sosyal beceri öğretimi araştırmalarının ve (c) sosyal beceri öğretim yöntemlerinin etkililik ve verimliliklerinin karşılaştırmalı olarak incelenebileceği araştırmaların yapılması önerilmektedir. 


\section{References}

Acar, Ç. (2015). Otizmli çocuklara sosyal becerilerin öğretiminde anneler tarafindan hazırlanarak sunulan sosyal öykü ve video modelle ögretim uygulamalarının karşılaştırllması [Comparing the effects of mother developed and delivered social stories and video modeling intervention on teaching children with Autism spectrum disorders]. Doctorate Dissertation, Abant İzzet Baysal University, Bolu, Turkey.

Akfirat-Önalan, F. (2004). Yaratıcı dramanın işitme engelli çocuklarda sosyal becerilerinin gelişimine etkisi [The effect of the creative drama on the social skills development of the hearing impaired]. Doctorate Dissertation, Ankara University, Ankara, Turkey.

Alptekin, S. (2010). Akranların sosyal becerilere model olduğu doğrudan ögretimin zihinsel engelli öğrencinin sosyal becerileri kazanmasl, sürdürmesi, genellemesi ve sosyal kabulüne etkisi [The effect of direct instruction with modeling the social skills by the peers of the mentally retarded student on his/her acquiring, maintaining and generalizing the social skills and his/her social acceptance]. Doctorate Dissertation, Gazi University, Ankara, Turkey.

Alptekin, S. (2012). Sosyal becerilerin zihinsel engelli öğrencilere doğrudan öğretim yaklaşımıla öğretimi [Teaching the social skills to the mentally retarded students through direct instruction approach]. Ondokuz Mayıs Üniversitesi Ĕgitim Fakültesi Dergisi, 31(1), 1-19.

Alptekin, S.\& Özyürek, M. (2013). Akranların sosyal becerilere model olduğu doğrudan öğretimin zihinsel engelli öğrencinin sosyal becerileri kazanması sürdürmesi genellemesi ve sosyal kabulüne etkisi [The effect of direct instruction with modeling the social skills by the peers of the mentally retarded student on his/her acquiring, maintaining and generalizing the social skills and his/her social acceptance]. The Journal of Academic Social Science Studies. International Journal of Social Science, 6(8), 31-58.

Avcıŏlu, H. (2001). Işsitme engelli çocuklara sosyal becerilerin öğretilmesinde işbirlikçi öğrenme yaklaşımı ile sunulan ögretim programının etkililiğinin incelenmesi [Examing the effectiveness of program development for teaching social skills to hearing impairet students based on cooperative learning]. Doctorate Dissertation, Ankara University, Ankara, Turkey.

Avcıoğlu, H. (2005). Etkinliklerle sosyal beceri ögretimi [Teaching social skills with activities]. Ankara: Kök Publishing.

Avcıoğlu, H. (2007). Sosyal becerileri değerlendirme ölçeğinin geçerlik ve güvenirlik çalışması (4-6 yaş) [Reliability and validity study of the social skills evaluation scale (Age 4-6)]. Abant İzet Baysal Üniversitesi Ë̆itim Fakültesi Dergisi, 7(2), 87-101.

Avcıoğlu, H. (2012a). Zihinsel yetersizliği olan çocuklara sosyal beceri kazandırmada işbirliğine dayalı öğrenme ve drama yöntemlerinin etkililiği [The effectiveness of cooperative learning and drama techniques in acquisition of social skills by the children with intellectual disabilities]. Eğitim ve Bilim, 37(163), 110-125.

Avcıoğlu, H. (2012b). Zihinsel yetersizliği olan çocuklara sosyal beceri kazandırmada kendini yönetme stratejileri doğrultusunda hazırlanan öğretim programının etkililiği [The effectiveness of the instructional programs based on self-management strategies in acquisition of social skills by the children with intellectual disabilities]. Kuram ve Uygulamada Eğitim Bilimleri Dergisi, 12(1), 345-351.

Avcıoğlu, H. (2013). Zihinsel yetersizliği olan öğrencilere selam verme becerisinin öğretiminde videoyla model olmanın etkililiği [Effectiveness of video modelling in training students with intellectual disabilities to greet people when they meet]. Kuram ve Uygulamada Eğitim Bilimleri Dergisi, 13, 455-477.

Bacanl1, H. (1999). Sosyal beceri eğitimi [Social skills training]. Ankara: Nobel Publishing.

Bellini, S., Peters, J. K., Benner, L. \& Hopf, A. (2007). A meta-analysis of school-based social skills interventions for children with autism spectrum disorders. Remedial and Special Education, 28(3), $153-162$.

Çadır, D. (2008). Zihinsel engelli öğrenciler için müzik terapi yöntemine göre hazırlanan sosyal beceri ögretim programının etkililiginin incelenmesi [Analysis for the affectiveness of social ability education program that is designed through musical therapy method for mentally disabled students]. Master Dissertation, Abant İzzet Baysal University, Bolu, Turkey. 
Çadır, D. \& Avcıoğlu, H. (2013). Zihinsel engelli öğrenciler için müzik terapi yöntemine göre hazırlanan sosyal beceri ögretim programının etkililiği [Analysıs for the affectıveness of social skills education program that is designed through musical therapy method for intellectual disability students]. Turkish International Journal of Special Education and Guidance \& Counseling, 2(1), 46-63.

Çakır, S. (2006). Zihin engelli öğrencilere doğrudan öğretim yaklaşımıyla sosyal beceri öğretiminin etkililiğinin incelenmesi [An investigation of effectiveness of the social skills training conducted through direct insruction approach formentally retarded students]. Master Dissertation, Gazi University, Ankara, Turkey.

Çelik, H. (2010). Zihinsel yetersizliği olan öğrencilere sosyal becerilerin ögretiminde kendi kendini yönetme tekniği ile sunulan ögretim programının etkililiğinin incelenmesi [Studying the effectiveness of an educational program presented with self-management techniques in teaching social skills to students suffering from mental deficiency]. Master Dissertation, Abant İzzet Baysal University, Bolu, Turkey.

Çifci, İ. (2001). Zihinsel engelli bireyler için hazırlanan bilişsel süreç yaklaşımına dayalı sosyal beceri programinin etkililiğinin incelenmesi [The effectiveness of social skills training program based on cognitive process approach for mentally retarded individuals]. Doctorate Dissertation, Ankara University, Ankara, Turkey.

Çifci, İ. \& Sucuoğlu, B. (2005). Bilişsel süreç yaklaşımıyla sosyal beceri öğretimi (5. Bs.) [Teaching social skills through cognitive process approach (5th ed.)]. Ankara: Kök Publishing.

Çolak, A. (2007). Kaynaştırma uygulanan bir ilköğretim sınıfindaki sosyal yeterlik özelliklerinin betimlenmesi ve iyileştirilmesi çallşmalar [An investigation of description and intervention efforts of social competence characteristics of a mainstreamed primary classroom]. Doctorate Dissertation, Anadolu University, Eskişehir, Turkey.

Dağseven-Emecen, D. (2011). Zihin engellilere sosyal becerilerin kazandırılmasında doğrudan öğretim ve bilişsel süreç yaklaşımlarının karşılaştırılması [Comparison of direct instruction and problem solving approach in teaching social skills to children with mental retardation]. Kuram ve Uygulamada Eğitim Bilimleri, 11(3), 10431419.

Eldeniz-Çetin, M. (2005). Zihin engelli öğrenciler için drama yöntemine göre hazırlanan sosyal beceri ögretim programinin etkililiginin incelenmesi [The study on the effectiveness of the social skill teaching programme prepared according to the drama method for the students with mental retardation]. Master Dissertation, Abant İzzet Baysal University, Bolu, Turkey.

Emecen, D. (2008). Zihinsel yetersizlikten etkilenmiş öğrencilere sosyal becerilerin kazandırılmasında doğrudan ögrretim ve bilişsel süreç yaklaşımları ile yapılan öğretimin etkililiklerinin ve verimliliklerinin karşılaştırılması [The comparison of effectiveness and efficiency of direct instruction and problem solving approachs in teaching of social skills for children with mental retardation]. Doctorate Dissertation, Gazi University, Ankara, Turkey.

Harper, C.B., Symon, J.B.G. \& Frea, W.D. (2008). Recess is time-in: Using peers to improve social skills of children with autism. Journal of Autism and Developmental Disorders, 38, 815-826.

Horner, R. H., Carr, E. G., Halle, J., Mcgee, G., Odom, S. \& Wolery, M. (2005). The use of single-subject research to identify evidence-based practice in special education. Exceptional Children, 71(2), 165-179.

İpek, A. (1998). Eğitimde dramanın zihinsel engelli çocukların sosyal gelişimleri üzerinde etkisinin incelenmesi [A Study on the effects of drama in education on social development of children with mental retardation]. Master Dissertation, Hacettepe University, Ankara, Turkey.

Mercer, D.C. \& Mercer, A.R. (2005). Teaching students with learning problems. (7th ed.). NJ: Pearson Publishing.

Odluyurt, S. (2013). Kaynaştırmaya devam eden otistik özellikler gösteren çocuklara kurallı oyun öğretiminde akranları tarafından doğrudan model olma ve videoyla model olma öğretiminin etkilerinin karşılaştırılması [A comparison of the effects of direct modeling and video modeling provided by peers to students with autism who are attending in rural play teaching in an inclusive setting]. Kuram ve Uygulamada Ĕ̆itim Bilimleri, 13(1), 523540. 
Odom, S. L., Brantlinger, E., Gersten, R., Horner, R.H., Thompson, B. \& Harris, K.R. (2005). Research in special education: Scientific methods and evidence-based practices. Exceptional Children, 71(2), 137-148.

Özaydın, L., Tekin-İftar, E. \& Kaner, S. (2008). Arkadaşlık becerilerini geliştirme programının özel gereksinimi olan okul öncesi çocuklarının sosyal etkileşimlerine etkisi [The effects of a friendship development program on the social interactions of the preschool children with special needs]. Ankara Üniversitesi Ĕ̈itim Bilimleri Fakültesi Özel Eğitim Dergisi, 9(1), 15-32.

Özokçu, O. (2008). Birlikte eğitim ortamlarındaki zihin engelli öğrencilere sosyal becerilerin kazandırılmasında doğrudan öğretim yönteminin etkililiğinin incelenmesi [The efectiveness of direct instruction method on mentally retarded students? social skills in mainstreaming settings]. Doctorate Dissertation, Ankara University, Ankara, Turkey.

Paterson, C. R. \& Arco, L. (2007). Using video modeling for generalizing toy play in children with autism. Behavior Modification, 31(5), 660-681.

Patton, M. Q. (2002). Qualitative research \& evaluation methods (3rd ed.). California: Sage Pub. Inc. Publishing.

Pierce, K. \& Schreibman, L. (1995). Increasing complex social behaviors in children with autism: Effects of peer-implemented pivotal response training. Journal of Applied Behavior Analysis, 28(3), 285-295.

Pierce, K. \& Schreibman, L. (1997). Multiple peer use of pivotal response training social behaviors of classmates with auitism: Results from trained and untrained peers. Journal of Applied Behavior Analysis, 30(1), 157- 160.

Sansosti, F. J.\& Powell-Smith, A. K. (2008). Using computer presented social stories and video models to increase the social communication skills of children with high functioning autism spectrum disorders. Journal of Positive Behavior Interventions, 10(3), 162-178.

Sazak, E. (2003). Zihin engelli birey için hazırlanan akran aracılı sosyal beceri öğretim programının etkililiğinin incelenmesi [The Effectiveness of peer tutoring social skills intervention program for individuals with mental retardation]. Master Dissertation, Abant İzzet Baysal University, Bolu, Turkey.

Scattone, D. (2008). Enhancing the conversation skills of a boy with asperger's disorder through social stories and video modeling. Autism Developmental Disorder, 38, 395-400.

Snell, M. E. \& Brown. F. (2011). Instruction of students with severe disabilities (7th ed.). Upper Saddle River, NJ: Pearson Publishing.

Tekin-İftar, E. (2012). Eğitim ve davranış bilimlerinde tek-denekli araştırmalar [Single-subject researches in education and behavioral sciences]. Ankara: Türk Psikologlar Derneği Yayınları.

Tekin-İftar, E. \& Kırcaali-İftar, G. (2001). Özel eğitimde yanlışsız öğretim yöntemleri [Errorless teaching methods in special education]. Ankara: Nobel Publishing.

Türer, H. (2010). Zihinsel engelli ögrencilere teşekkür etme ve özür dileme becerilerinin öğretiminde doğrudan ögretim yönteminin etkililiğ i [Effeciency of directly teaching method at thanking and apoligising abilities to students with mentally retarded]. Master Dissertation, Selçuk University, Konya, Turkey.

Yıkmış, A. (2005). Etkileşime dayalı matematik öğretimi [Interaction based teaching mathematics]. Ankara: Kök Publishing.

Yücesoy-Özkan, Ş. \& Sönmez, M. (2011). Yetersizliği olan bireylerle yapılmış ve kendini yönetme stratejilerinin kullanıldığ 1 tek denekli araştırmaların incelenmesi: bir meta-analiz çalışması [Examination of single subject studies conducted on individuals with disabilities by using self management strategies: a meta analysis study]. Kuram ve Uygulamada Eğitim Bilimleri, 11(2), 795-821. 